\title{
Androgens and Androgen Receptor Actions on Bone Health and Disease: From Androgen Deficiency to Androgen Therapy
}

\author{
Jia-Feng Chen ${ }^{1,2}$, Pei-Wen Lin ${ }^{2,3}$, Yi-Ru Tsai ${ }^{2,3,4}$, Yi-Chien Yang ${ }^{2,5}$ and Hong-Yo Kang $2,3, * \mathbb{C}$ \\ 1 Division of Rheumatology, Allergy and Immunology, Department of Internal Medicine, \\ Kaohsiung Chang-Gung Memorial Hospital and Chang Gung University, College of Medicine, \\ Kaohsiung 833, Taiwan; uporchid@cgmh.org.tw \\ 2 Graduate Institute of Clinical Medical Sciences, College of Medicine, Chang Gung University, \\ Kaohsiung 833, Taiwan; peiwen349@gmail.com (P.-W.L.); sexhappiness@gmail.com (Y.-R.T.); \\ yichienyang@gmail.com (Y.-C.Y.) \\ 3 Center for Menopause and Reproductive Medicine Research, Department of Obstetrics and Gynecology, \\ Kaohsiung Chang-Gung Memorial Hospital and Chang Gung University, College of Medicine, \\ Kaohsiung 833, Taiwan \\ 4 An-Ten Obstetrics and Gynecology Clinic, Kaohsiung 802, Taiwan \\ 5 Department of Dermatology, Kaohsiung Chang Gung Memorial Hospital, Kaohsiung 833, Taiwan \\ * $\quad$ Correspondence: hkang3@mail.cgu.edu.tw; Tel.: +886-7-731-7123 (ext. 8898)
}

Received: 31 August 2019; Accepted: 22 October 2019; Published: 25 October 2019

\begin{abstract}
Androgens are not only essential for bone development but for the maintenance of bone mass. Therefore, conditions with androgen deficiency, such as male hypogonadism, androgen-insensitive syndromes, and prostate cancer with androgen deprivation therapy are strongly associated with bone loss and increased fracture risk. Here we summarize the skeletal effects of androgens-androgen receptors (AR) actions based on in vitro and in vivo studies from animals and humans, and discuss bone loss due to androgens/AR deficiency to clarify the molecular basis for the anabolic action of androgens and AR in bone homeostasis and unravel the functions of androgen/AR signaling in healthy and disease states. Moreover, we provide evidence for the skeletal benefits of androgen therapy and elucidate why androgens are more beneficial than male sexual hormones, highlighting their therapeutic potential as osteoanabolic steroids in improving bone fracture repair. Finally, the application of selective androgen receptor modulators may provide new approaches for the treatment of osteoporosis and fractures as well as building stronger bones in diseases dependent on androgens/AR status.
\end{abstract}

Keywords: androgens; androgen receptor; osteoporosis sex differences; and bone regeneration

\section{Introduction}

The discovery of androgen actions initiated in the 19th century with the idea of self-injection with testicular extracts from pigs or dogs to restore vitality by Dr. Charles Brown-Séquard [1]. It was known that the development and maintenance of male characteristics are modulated through androgen receptors (AR) [2], also designated as NR3C4 (nuclear receptor subfamily 3 group C member 4). Androgens bind to AR in the cytoplasm, translocating into the nucleus, and binding to DNA to function as a transcription factor. [2]. Androgens/AR signaling axis is a requisite for androgenic phenotype expression through regulating diverse responses at target tissues, including bones. The most important androgens, principally testosterone (T) and $5 \alpha$-dihydrotestosterone (DHT), influence the human skeleton in both males and females. Testosterone exerts anabolic effects on the skeleton 
through signal transduction via (a) binding to AR, and (b) conversion to 17-beta estradiol (E2) via the enzyme aromatase (from cytochrome P450 family) which then binds to estrogen receptors (ERs) [3,4]. Conversely, both circulating and peripheral effects of testosterone on the body depend on its conversion to DHT by the local enzyme $5 \alpha$-reductase (SRD5A; type I and II) in target tissues. Both T and DHT bind to AR, but DHT has a higher affinity to AR in many tissues. The activation of AR and ER $\alpha$, but not ER $\beta$, is associated with maintenance of the trabecular bone. The effects of ER $\alpha$ activation preserved the thickness and number of trabeculae, while AR preserved the number of trabeculae [5]. For cortical bone, the bone-sparing effects were majorly mediated by ER $\alpha$, but not AR or ER $\beta$ for the maintenance of the cortical thickness, volumetric density, and mechanical strength [5]. Activation of $\mathrm{ER} \alpha$ may have direct impacts on bone, or indirectly through increasing Insulin-like growth factor-1 (IGF-1) in serum [5].

\section{Androgens and Androgen Receptors (AR) on Bone Health}

\subsection{The Effects of Androgen and Androgen Receptors on Bone Growth}

Androgens are known to stimulate longitudinal bone growth as well as radial bone growth, thereby increasing the cortical bone size. The longitudinal bone grows through the endochondral bone formation and epiphyseal plate growth, whereas the radial bone grows through periosteal apposition. Cartilage cells, predominantly chondrocytes, proliferate and differentiate under the regulation of various endocrines, such as growth hormone (GH), insulin-like growth factor-I (IGF-I), transforming growth factor (TGF-beta), and vitamin D metabolites [6]. Longitudinal bone growth is governed by sex hormones that exert biphasic effects during adolescence-as puberty begins, androgen and estrogen stimulate endochondral bone development, but the epiphyseal growth plate closure is majorly mediated by estrogen via ER at the end of puberty through aromatization of androgen to estrogen [7]. Estrogen demonstrates biphasic effects on epiphyseal growth, where low concentrations, as male sex physiologically presented, can stimulate epiphyseal growth, whereas higher concentration level, as female sex presents, is associated with the arrest of bone growth [8]. This is testified by the observed growth spurt in puberty due to the delayed closure of epiphyses in estrogen-deficient individuals (e.g., mutated aromatase gene) or estrogen-resistant cases (ER gene mutation) $[9,10]$.

A greater radial bone expansion, comprising enlargement of bone diameter and increase of cortical thickness, is characteristic for bone growth in male puberty. Accelerated periosteal bone apposition in men than in women [11] is conventionally supposed to result from the stimulatory effects of androgens on periosteal bone through AR in men and the inhibitory effects of estrogens in women during puberty. Experiments in transgenic mice provided evidence that estrogen may also stimulate radial bone growth. Observational studies on men with aromatase deficiency, characterized by normal serum androgen but undetectable levels of estrogen, exhibit low bone mass and areal density. Taking these findings together, periosteal bone expension is not only mediated by androgen, but also estrogen.

Previous studies documented sex-related dimorphism in the cortical bone size, and strength in rodents and to a lesser extent, in humans [12]. While it is known that androgen actions enhance radial bone growth through increasing periosteal apposition in pubertal male rodents [13], their postpubertal effects at the periosteal surface are still unclear. Considering higher fracture risk in females and that volumetric bone density does not differ between the genders significantly, higher bone strength in males is likely a consequence of larger bones. In that context, it will be especially valuable to elucidate how bone size is regulated and which biochemical mechanisms drive periosteal apposition of bone material. It was suggested that androgen effects on radial bone growth are mediated both via AR and ER signaling pathways in male mice [14]; nevertheless, it is still unknown how these pathways are mutually related. Periosteal expansion is mediated via AR and ER $\alpha$ pathway [15]. However, the target cell(s) mediating these effects remain unclear. It was shown that a deficiency of estrogens by aromatase inhibitors impairs periosteal bone formation and endosteal bone resorption during radial bone growth in orchidectomized male rats [16]. The longitudinal bone growth is facilitated by chondrocytes at the 
epiphyseal plates, closure of which is mediated by estrogens on the chondrocytes [15]. This scenario might explain that the earlier growth arrest is attributed to the earlier onset of puberty in females. However, further studies are required to reveal molecular mechanisms behind these observations (e.g., direct or indirect mechanisms, growth hormone (GH)/IGF-1 axis activation at different time points and concentrations).

The GH/IGF-1 axis is essential in achieving a normal longitudinal bone growth and bone mass acquisition in the association with sex steroids. GH not only directly promotes differentiation of mesenchymal stem cells (MSC) into osteoblasts but stimulates osteoblast proliferation [17,18]. GH may promote osteoblast differentiation indirectly by upregulating bone morphogenetic proteins (BMPs) and IGF-1/IGF-2B [19]. IGF-1, majorly produced in the liver, exerts stimulatory effects through binding to IGF-1 receptors on osteoblasts resulting in cell differentiation [20], and the serum levels are positively correlated with BMD in older women and men [21]. Circulating estrogen, whether endogenous or exogenous in origin, may modulate the GH/IGF-1 axis, influencing bone turnover. In a GH receptor gene knockout (GHRKO) mouse study, GH/IGF-I activation is not involved in the development and maintenance of trabecular bone, while androgens stimulate trabecular bone modeling independently from GH/IGH-1. However, GH/IGF-1 activation are the major determinants of periosteal bone growth to obtain optimal periosteal bone growth [13].

\subsection{The Effects of Androgen and Androgen Receptors on Bone Homeostasis}

Application of AR transgenic and AR knockout (ARKO) mouse models have recently shed more light on the AR role in androgen effects on bone homeostasis [22]. Previous studies showed different effects of androgens depending on the species, age, sex, and specific bone compartment; yet, it seems that irrespective of age or sex, they preserve trabecular bone integrity. Under the androgen effects, the trabecular bone may be maintained directly by osteocytes, or indirectly by inhibiting osteoclastogenesis through interaction with osteoblast precursors, while AR has no role on osteoclasts [23-25]. ARKO mice have shown significant bone deterioration already at a young age. Nevertheless, whether sex hormone actions influence bone homeostasis in aged male and female mice through the regulation of AR activity remains unclear. Recent studies have evaluated how sex hormone treatment influences bone microarchitecture in ARKO mice and showed that bone mass decreased in ARKO mice of both sexes at six, 18, and 30 weeks of age, and that AR deficiency has a greater effect on bone microstructure at six weeks in males. Gonadectomy did not further worsen the bone microstructure in ARKO mice at 18 weeks of age [26]. Bone strength and stiffness decreased in female and male ARKO mice, respectively. E2, but not DHT or dehydroepiandrosterone (DHEA) treatment rescued trabecular bone mass and bone stiffness in both sexes of gonadectomized ARKO mice [26]. In summary, the inactivation of AR affects bone remodeling in both male and female. Both trabecular and cortical bones are affected. However, the influences vary according to age, gender, and the type of supplemented hormones. Additional studies are required to unravel the detailed mechanisms of interactions in bone homeostasis.

\subsection{Regulation of Bone Turnover in Men}

Bone turnover markers (BTM), products derived from bone matrix or bone cells during bone remodeling, could be categorized by either catabolic markers, such as $\mathrm{C}$ - or $\mathrm{N}$-terminal telopeptide of type I collagen (CTX or NTX), pyridinolines, or anabolic markers, such as procollagen type I $\mathrm{N}$-terminal propeptide (PINP) bone alkaline phosphatase (bone ALP), or osteocalcin (OC). For men, the bone turnover markers are highest in the second or third decade, then mildly decrease hereafter. In young men, the relationship between increased bone turnover and high levels of sex hormone or IGF-1 is stronger than that of old men [27]. Data from the Dubbo Osteoporosis Epidemiology Study, MINOS cohort study of osteoporosis in men, and the Osteoporotic Fractures in Men (MrOS) Study are unable to prove conventional BTM as an independent biomarker that could predict fragility fractures in older men [28-30]. 
AR is predominantly expressed in osteoblasts and osteocytes, but not on osteoclasts [24,31,32]. It has been shown that osteoclast-specific ARKO mice have no changes in osteoclast surface, bone microarchitecture, or the response to orchidectomy and androgen replacement, suggesting that the AR in osteoclasts has no critical role for bone maintenance in mice [31]. Regulation of osteoclast function is primarily mediated by estrogens and ERs, since $\mathrm{T}$ may control osteoclast indirectly by aromatization to E2, or by inhibiting the production of interleukin-6, which is essential for the maturation of osteoclast precursors [33]. AR in osteoblasts is up-regulated by androgen, estrogen, and 1,25-dihydroxyvitamin $\mathrm{D}$ to stimulate osteoblast proliferation, differentiation, and synthesis of extracellular matrix protein and mineralization $[34,35]$. AR in osteocytes had a direct role in maintaining skeletal integrity and bone quality [24]. However, AR had no role in the direct action on osteoclasts in animal model studies [31].

\section{The Impacts of Androgen Deficiency/Excess on Bone Remodeling in Human}

\subsection{Hypogonadism in Men (Androgen Deficiency)}

Androgen deficiency manifested as a delay in sexual development, reduced testicular volume, axillary and pubic hair loss, and other suggestive symptoms included reduced libido, erectile dysfunction, gynecomastia, low sperm count and skeletal disorders, such as height loss, low traumatic fracture, or decreased BMD [36]. To diagnose hypogonadism in men, apart from the above-listed symptoms and signs, the patient should show consistently low $\mathrm{T}$ levels (total $\mathrm{T}$ and free $\mathrm{T}$ levels in serum) [36]. Bone mineral density (BMD) is notably lower in hypogonadal men (especially at the spine-a predominantly cancellous bone site) than in their healthy counterparts [37]. Impaired skeletal growth with lower peak bone mass achieved reflects in decreased BMD at the spine, femur, and distal sites of non-dominant radial bone [38,39]. Moreover, it was reported recently that hypogonadism is associated with a deteriorated trabecular microarchitecture of the distal tibia [40]. The significant relationship between pretreatment serum $\mathrm{T}$ levels and BMD was found in congenital hypogonadal men [41]. One large prospective, multicenter-based cohort, MrOS study, followed 2908 men, discovered that free testosterone was a positive predictor for BMD in the total body, total hip, and femur trochanter. Also, a low $\mathrm{T}$ level was associated with an increased number of fragility fractures, including vertebral fracture [42]. Other studies in men with hip or vertebral fractures highlighted that a number of individuals were hypogonadal $[43,44]$. T supplementary therapy has also been proved to contribute to BMD increment in men with low testosterone levels in several studies [41,45-50].

While some studies in adult hypogonadal men showed a major increase in bone resorption and a lesser increase in bone formation, similar to postmenopausal women [51], others emphasized low bone formation in these individuals $[52,53]$. The previous studies with a histological survey of follow-up biopsies supported the concept that $\mathrm{T}$ stimulates bone formation and mineralization [53]. A reduction in plasma 1,25-dihydroxyvitamin $\mathrm{D}(1,25(\mathrm{OH}) 2 \mathrm{D})$ was found to be a major risk factor for osteoporosis in hypogonadal men [52]. Following T supplementary therapy significantly increases in $1,25(\mathrm{OH}) 2 \mathrm{D} /$ calcium absorption [40] and serum bone formation markers [42], implicating that androgen is contributory to bone formation. In Table 1, we summarized different clinical conditions associated with androgen deficiency or excess, and discuss them seperately. 
Table 1. Summary of impacts on bone in different disease associated with androgen deficiency or excess.

\begin{tabular}{|c|c|c|c|}
\hline & Clinical Manifestation & Impacts on Bone in Adults & Reference \\
\hline \multicolumn{4}{|l|}{ Androgen Deficiency } \\
\hline $\begin{array}{l}\text { Isolated hypogonadotropic } \\
\text { hypogonadism (IHH) }\end{array}$ & $\begin{array}{l}\text { Delayed puberty in late } \\
\text { teens or early twenties. }\end{array}$ & $\begin{array}{l}\text { - lower lumbar spine, femoral neck, trochanter, } \\
\text { and radius BMD. } \\
\text { - No data for possible increase fracture risk. }\end{array}$ & [54] \\
\hline Klinefelter's syndrome (KS) & $\begin{array}{l}\text { tall stature, small testes, } \\
\text { aspermatogenesis, } \\
\text { gynecomastia, } \\
\text { diminished body hair }\end{array}$ & $\begin{array}{l}\text { - Lower spine, hip, and forearm BMD in adult KS } \\
\text { - Increase fracture risk at the femoral area and } \\
\text { mortality rate associated with hip fracture is } 39 \% \text {. }\end{array}$ & {$[55,56]$} \\
\hline $\begin{array}{l}\text { Constitutional delay of growth } \\
\text { and puberty (CDGP) }\end{array}$ & $\begin{array}{l}\text { short stature, delay bone } \\
\text { age, and puberty }\end{array}$ & $\begin{array}{l}\text { - Failed to reach target height or predicted } \\
\text { adult height. } \\
\text { - Significant increase of BMD in stage III and IV of } \\
\text { puberty stages, and normal lumbar and femoral } \\
\text { neck Volumetric BMD in adults. } \\
\text { - No increased risk for fracture. }\end{array}$ & [57-59] \\
\hline Androgen deprivation therapy & $\begin{array}{l}\text { Flushing, decrease libido, } \\
\text { anemia, insulin } \\
\text { resistance. }\end{array}$ & $\begin{array}{l}\text { - In prostate cancer patients, BMD decreased } 3.7 \% \\
\text { at the lumbar spine and } 2.1 \% \text { at the femoral neck } \\
\text { within the } 1^{\text {st }} \text { year. } \\
\text { - } 2.7-8.1 \% \text { fracture within five years. }\end{array}$ & [60-62] \\
\hline Aging & $\begin{array}{l}\text { Degeneration of systemic } \\
\text { change, sleep } \\
\text { disturbance, decrease } \\
\text { libido. }\end{array}$ & $\begin{array}{l}\text { - In women before menopause, an annual } \\
\text { reduction rate }<0.4 \% \text { and an increase to } 1.2 \% \\
\text { after menopause. In men, continuous bone loss in } \\
\text { the hip after peak bone mass after } 50 \text { years }\end{array}$ & [63] \\
\hline $\begin{array}{l}\text { Androgen insensitivity } \\
\text { syndrome (AIS) }\end{array}$ & $\begin{array}{l}\text { 46,XY karyotype, with } \\
\text { under masculinized } \\
\text { external genitalia } \\
\text { depends on residual AR } \\
\text { function. Gynecomastia } \\
\text { at puberty and infertility } \\
\text { in adulthood }\end{array}$ & $\begin{array}{l}\text { - Normal pubertal growth for females in CAIS, } \\
\text { appropriate epiphyseal maturation at } \\
\text { growth cessation. } \\
\text { Decrease BMD at lumbar spine. }\end{array}$ & [64-66] \\
\hline \multicolumn{4}{|l|}{ Androgen excess } \\
\hline $\begin{array}{l}\text { Polycystic ovary } \\
\text { syndrome (PCOS) }\end{array}$ & $\begin{array}{l}\text { Hirsutism, acne, alopecia, } \\
\text { seborrhea. Subfertility, } \\
\text { menstrual dysfunction. } \\
\text { Endometrial hyperplasia }\end{array}$ & $\begin{array}{l}\text { - No difference of BMD at the hip. No difference or } \\
\text { lower spine BMD compared to healthy control in } \\
\text { two studies. } \\
\text { Decrease or increase fracture risk were both } \\
\text { reported, may dependent on BMI. }\end{array}$ & [67-70] \\
\hline
\end{tabular}

\subsection{Isolated Hypogonadotropic Hypogonadism (IHH)}

In contrast to other types of male hypogonadotropic hypogonadism, IHH is an early and complete form of hypogonadism with isolated sex steroid deficiency and no other metabolic abnormalities, which makes it a good model to examine the effects of sex steroids and sex steroid deficiencies in men. Compared with age-matched controls, patients with IHH have lower bone density at the spine and radius, not only before but also after growth plate closure [71]. Interestingly, both areal and volumetric bone density are reduced. This suggests that the exact bone composition is impaired in the context of IHH. In these patients, assessing bone turnover has produced inconsistent results, demonstrating histomorphometric evidence for low-turnover osteoporosis in some patients [72] but increased levels of markers of bone formation and resorption in others [54].

There is also data about lower bone density (at radius and spine) in hyperprolactinemic hypogonadal men [54,73]. Nevertheless, in these men, cortical bone density could be improved by $\mathrm{T}$ supplementation, regardless of the prolactin levels, emphasizing hypogonadism as the primary factor for impaired bone homeostasis in these cases [74].

\subsection{Klinefelter's Syndrome (KS)}

Klinefelter's syndrome (KS), first reported in 1942 by Klinefelter et al., represents the presence of an extra $\mathrm{X}$ chromosome in a male karyotype, resulting in a typical phenotype which includes tall stature, small testes, aspermatogenesis, gynecomastia, diminished body hair, and other signs of androgen deficiency [75]. KS is recognized as the most common form of hypergonadotropic hypogonadism resulting in functional and structural testicular insufficiency during puberty. Impaired bone metabolism 
begins in early life, and children and adolescents with this syndrome could exhibit impaired bone structure as reflected in altered ultrasound parameters of phalanges, significantly lower serum 1,25(OH)2D level, markers of bone formation, and higher parathyroid hormone (PTH) level [76]. The long-term consequence of adult KS demonstrated universally lowered BMD at the spine, hip, and forearm than the age-matched healthy controls, as well as lower 1,25(OH)2D level. However, $\mathrm{T}$ is not an independent predictor for BMD [56]. KS patients are prone to having higher risks of fracture leading to morbidities and mortalities [77-79]. Although a positive effect on bone density was reported if testosterone treatment was initiated before the age of 20 years [80], in a three-year-followup study, $\mathrm{T}$ therapy in KS only increased lumbar spine BMD, but failed to improve parameters evaluated based on the trabecular bone score (TBS) or hip structure analysis (HSA) [81]. Interestingly, even patients on long-term T supplementation still showed low BMD [82,83], and several studies emphasized ill correlation of the serum $\mathrm{T}$ level and bone parameters $[56,84]$. This observation raises the question whether androgen deficiency is the main reason for the low BMD and whether T replacement should be the primary treatment choice to improve BMD in this specific group of patients; moreover, it suggests that bone deterioration in these patients may be, at least in part, independent of the actual hypogonadism. These results may also reflect the fact that KS patients display varying degrees of hypogonadism, where only severe hypogonadism may be linked to bone loss $[85,86]$. Considering the methodological limitations of the majority of previous studies (small sample size, lack of control group), large prospective and controlled trials are needed to elucidate how the bone structure is influenced by different levels of hypogonadism and T replacement.

\subsection{Constitutional Delay of Growth and Puberty (CDGP)}

Transient hypogonadotropic hypogonadism or constitutional delay of growth and puberty (CDGP) is the most common cause of delayed puberty, characterized by delayed skeletal age and a family history of delayed growth and puberty. Compared to healthy children, boys with CDGP have normal bone turnover markers, the BMD increases in a similar manner [87]. In boys with CDGP, androgen therapy proved useful to improve bone mass [88] and calcium absorption/retention in bone [89]. In clinical studies, androgen treatment contributes to growth velocity only, but it does not affect the gain of adult height [90-92]. Therefore, considering the high likelihood of the spontaneous restoration of normal pubertal development and attainment of their mid-parental target height, it is acceptable that observation and reassurance are a reasonable strategy [90].

\subsection{Androgen Deprivation Therapy and Castration}

It was reported that in men with advanced prostate cancer, androgen deprivation therapy (ADT) leads to accelerated bone degradation and increased risk to sustain a bone fracture $[93,94]$, which resembles bone deterioration occurring in ovariectomized or early postmenopausal women. A meta-analysis in prostate cancer patients who underwent ADT showed a significant decline of BMD within three years follow-up, with the mean decline of $3.7 \%, 3.1 \%$, and $1.6 \%$ in the regions of the lumbar spine, femoral neck, and total hip, respectively; these rates were faster than the yearly bone loss rate, around $0.5-1.0 \%$ in the normal middle-aged men [95]. Nevertheless, it should be noted that many prostate cancer patients could already have decreased BMD even before ADT was started [96]. A long-term prospective study following five years enrolled more than 50,000 men with prostatic cancer, discovering a significantly higher fracture rate developed in ADT patients compared to non-ADT after adjusting confounding factors (19.4\% in ADT vs. $12.6 \%$ in non-ADT, $p<0.001)$ [97]. Non-metastatic prostate cancer patients who underwent ADT without anti-resorptive therapy may suffer from a $21-37 \%$ increase in fracture risk [97-99]. Fracture risk in these patients may further increase due to the decreased lean mass secondary to androgen deficiency [100-102].

Based on these findings, there is much resemblance in bone deterioration between androgen-deficient men and postmenopausal women or hypogonadal animals. In this sense, imbalances in bone remodeling with a shift to resorption would cause net bone loss, which is evident 
at intracortical or endocortical surfaces in the appendicular skeleton and vertebral bone [103,104]. That would signify that sex steroid deficiency in men leads to high-turnover osteoporosis, too. Despite the lack of direct microstructural confirmation for this notion, clinical experience clearly shows that bisphosphonates (etidronate [105], i.v. pamidronate [106], zoledronic acid [107])—as turnover suppressors could prevent bone loss in those patients and may represent a sound therapeutic approach after castration.

\subsection{Aging}

Circulating $\mathrm{T}$ is transported predominantly by sex hormone-binding globulin (SHBG), which controls the amount of $\mathrm{T}$ in the body. SHBG-bound $\mathrm{T}$ is biologically inactive due to high affinity, whereas free $\mathrm{T}$ (approximately 2-3\%) [108] and albumin-bound T are considered bioavailable, and correlate better with BMD and muscle mass than total $\mathrm{T}[109,110]$. In aging men, total T declined at a speed of $1.6 \%$ per year, while $2-3 \%$ per year for the bioavailable T [111]. However, SHGB level increases with aging, resulting in a greater reduction of bioavailable T level [111]. Total and free Serum $\mathrm{T}$ inversely correlated with age and are associated with sexual symptoms, physical activity, and metabolic conditions in different cohorts [112-114]. The reference range of $T$, influenced by races, regions, timing of sample collection, and laboratory methods, need to be harmonized to avoid inter-cohort variation [115].

Aging in men results in a progressive reduction of hypothalamic-pituitary-gonadal (HPG) axis function, decreasing testosterone secretion through both central and peripheral origins. Data from the Osteoporotic Fractures in Men Study (MrOS) indicated that sex hormone deficiency was associated with higher prevalence of osteoporosis at baseline and greater loss of BMD over time in old age men accompanied with parallel T and E2 decline, of which 3\% were T deficient, 3.2\% were E2 deficient, and $0.7 \%$ were deficient in both. In old age men, there was a threshold level of E2 for fracture [116] but no association between total $\mathrm{T}$ and fracture, implicating that $\mathrm{E} 2$, but not $\mathrm{T}$, may be the major sex hormone associated with fracture risk in older men. On the contrary, some studies indicated that serum $\mathrm{T}$ is associated with fractures independently [42] and more powerfully than E2 [117]. For instance, high bone resorption in men who sustained a hip fracture correlated well with low serum T levels [118]. However, old age and sex hormone deficiency might be two distinct risk factors of cortical bone loss in old age from an animal study, which addressed the major mechanism of estrogen deficiency in bone through an increase osteoclastogenesis, whereas aging was through a decrease in osteoblastogenesis in combination with an increase osteoclastogenesis [119].

In contrast, there are scarce proofs of the beneficial impact of androgens in postmenopausal women. It is a fact that adrenal androgens (e.g., DHEA-S) serum levels drop by $70 \%$ in menopause) [120,121], but we do not know how that impacts bone loss. While there were no prospective studies on the relationship with fracture risk, previous cross-sectional studies failed to find any consistent relationship between serum DHEA-S and BMD $[122,123]$. Further studies are also needed to clarify whether DHEA-S has direct androgen/AR-mediated effects in the skeleton, or merely serves as a source for aromatization into estrogens.

\subsection{Androgen Insensitivity Syndrome (AIS)}

Androgen insensitivity syndrome (AIS) is caused by a mutation in the gene encoding the AR (Xq11-q12) [124]. AIS affects individuals with a 46, XY karyotype and its presentation usually involves the presence of feminized external genitalia at birth, abnormal development of secondary sexual traits in puberty, and infertility $[124,125]$. According to the range of defects in androgen action and appearance of external genitalia, AIS is subcategorized as complete form of AIS (CAIS) with female genitalia, partial androgen insensitivity syndrome (PAIS) with ambiguous genitalia, or with the predomination of either sex, and the mild form (mild androgen insensitivity syndrome, MAIS) in which external genitalia are typically males [125]. The therapeutic strategy relies on the reinforcement of the sexual identity, as well as planning the gonadectomy and hormone replacement therapy. 
Adult CAIS women showed decreased BMD values [126,127] both before and after gonadectomy due to a combination of skeletal resistance to androgen action and estrogen deficiency [128]. Although reduced BMD may stem from the impaired function of AR, there is still a debate on the association between gonadectomy and BMD [126,127]. AR signaling seems to influence trabecular bone preferentially $[65,126]$. In AIS women with intact gonads, BMD loss predominantly developed at the lumbar spine rather than the femoral neck $[65,129,130]$. One previous study revealed that the femoral neck in CAIS with intact gonads was within the normal range [127]. As shown in animal models, AR-dependent maintenance of cancellous bone targets osteoblasts and osteocytes, the leading players of matrix synthesis and mineralization [24,127,131,132].

A reduction in the lumbar and femoral neck BMD was reported in AIS women who underwent gonadectomy $[127,128,133]$, and BMD reduction at the lumbar spine is more profound than that at the femoral neck $[65,128,134]$. However, these studies may enroll participants affected by $46, X Y$ sex disorders other than AIS [127,134]. It is well established that the decline in BMD can be regarded as a major determinant of fracture risk [135], but the fracture rate of AIS was rarely investigated from previous studies and reviews. Only one study reported a high fracture rate (27.3\%) in women with removed gonads [134]. Since decreased BMD could be found in some cases with intact gonads, it was suggested that supplementing with additional estrogens could be helpful for them even if they demonstrate intact testes [136]. It is also essential to optimize doses/formulations of hormone replacement therapy in CAIS women following gonadectomy, preferably using transdermal estrogen patches and strictly monitoring compliance.

\subsection{Hyperandrogenism (Androgen Excessive)}

Numerous studies showed an increased BMD in hyperandrogenemia, such as in women with polycystic ovary syndrome (PCOS) $[25,137,138]$. In contrast, some studies demonstrated lower BMD in PCOS compared to controls, although the serum $\mathrm{T}$ concentration was higher than the controls [68,139]. No difference in BMD and postmenopausal fracture incidence between PCOS patients and healthy controls have been reported $[67,140]$. These conflict results may imply that in different study groups, the variable degree of the excess of androgen production in PCOS may partially preserve the BMD but did not always overcome the deleterious bone effects of estrogen deficiency. Also, the effect of hyperandrogenism may be differential across the various bone sites according to different androgen $[141,142]$. PCOS model of androgen excess has a number of limitations, such as confounding factors that are difficult to control in case-control study design (differences in body mass index (BMI), body composition, and menstrual irregularities), and often the crude determination of androgen excess by the presence of hirsutism. Nevertheless, PCOS studies contributed to the understanding of the link between hirsutism and peak BMD (e.g., compared to age-matched controls, hirsute women showed higher peak BMD, even after adjustment for BMI) $[143,144]$. Owing to the findings from the peripheral quantitative computed tomography (pQCT) study [138], increased BMD reflects real changes in bone composition, not just the changes in bone size [141]. However, it is still unknown if these positive effects are mediated through AR or rely on aromatization. It was observed that PCOS patients with high BMI tend to have higher BMD than those with normal or low BMI, signifying the importance of aromatization within fat tissue [145]. Additional research is warranted to clarify potential skeletal effects of other metabolic abnormalities in PCOS (such as low levels of SHBG with increased hormone bioavailability, or high insulin level) [145]. Insulin appears to be one of the most crucial positive bone growth stimulators through direct and indirect effects on bone formation, and BMD is a significant negative correlation with insulin sensitivity index $[140,146]$. Insulin resistance and hyperinsulinemia may directly stimulate production of androgens via ovarian tissue steroidogenesis by inhibiting hepatic sex hormone-binding globulin (SHBG) production, thus increasing free testosterone [147-149].

Some of the treatment options used in hirsute women with androgen excess (namely, gonadotropin-releasing hormone $(\mathrm{GnRH})$ agonists and AR antagonists, alone or together) may have adverse effects on bone metabolism. For instance, GnRH agonist therapy would suppress 
estrogen and androgen levels and thereby facilitate bone loss in hirsute women, although the effect is preventable [150]. While in a six-month period, the use of spironolactone as an AR antagonist was able to preserve BMD in hirsute women on GnRH agonists [151], spironolactone was usually associated with a reduced BMD [152]. On the other hand, another AR antagonist flutamide, when administered alone, did not affect BMD values of the lumbar spine [153] Metformin treatment was associated with reduced bone turnover, as suggested by reductions in markers of bone formation and resorption, leading to slower bone remodeling in premenopausal women with PCOS[154]. However, controversy still exists, and these findings should be taken with caution as they were based on uncontrolled, short-term studies. Adjustment for differences in age, duration of amenorrhoea, lifestyle factors, differences in body composition, or weight distribution, BMI, and various ethnic groups could provide a better understanding of the relation between bone and PCOS.

\section{Androgens/AR Actions on Skeletons in Animal Studies}

Female mouse ovariectomy (OVX)-induced surgical castration, and male mouse orchiectomy (ORX) represent the most commonly used surgical castration method for studying the effects of skeletal sex steroids. Cortical bone growth was also observed in male ORX mice, as described in rats [155-157]. Female mice did not demonstrate remarkable periosteal expansion after ovariectomy compared with rats [158,159]. In cancellous bone, both OVX [158-161] and ORX [33,156,157,160,162] led to a loss of bone mass, that was associated with raised bone turnover markers $[156,158]$, and thus OVX and ORX mice are increasingly considered to be animal models of steroid action studies in postmenopausal-like osteoporosis $[15,25]$. Besides, DHT was able to reverse the loss of cancellous bone, but DHT did not prevent cortical thinning induced by ORX [163]. In summary, both DHT and T in OVX female and ORX male rats were protective for bone integrity, in particular in the cancellous bone. DHT does not appear to be as effective as $\mathrm{T}$ in cortical bones, maybe because $\mathrm{T}$ can undergo aromatization through estrogens and stimulation of the ERs.

Testosterone supplementation can prevent bone loss effectively in ORX mice cancellous bone [33,156], and DHT [164] and estrogens [155,156,159,160,162,164] also seem to help preserve bone after gonadectomy in both sexes. Phytoestrogens have similar bone-preservation effects observed in OVX [165] and ORX mice [166]. Therefore, loss of cancellous bone in mice, regardless of sex, could be prevented by both androgens and estrogens. Also, $\mathrm{T}$ increases the cortical region of ORX mice [5,167], and delivery of $\mathrm{T}$ with biodegradable stents is effective in promoting bone healing in femur fractures of mice with critical size segmental defects. [168].

Other animal studies involved animals with knockouts for AR and ERs. Those studies mainly revealed the roles taken by $\mathrm{AR}$ and ERs to manipulate the genetic conditions of male animals. For instance, it showed that ER rather than AR activation involves longitudinal bone growth [169]. In addition, knockout mice have shown that both $\mathrm{ER} \alpha$ and AR are involved in enhancing cortical radial bone growth. Unlike AR and $\mathrm{ER} \alpha, \mathrm{ER} \beta$ cannot mediate retention of sex steroids in the cancellous bone $[162,170]$. Furthermore, two modes of action were suggested for T: a direct action via AR and indirect action via $\mathrm{ER} \alpha$ through aromatization [171].

Transgenic expressed AR transgenic mice driven by a $3.6 \mathrm{~kb}$ fragment showed that AR was overexpressed in all cells of osteoblast lineage [172-174], and expressed a phenotype of reduced turnover leading to reduced bone strength [175]. Unlike in wild type mice, DHT treatment was not able to increase cortical thickness and restore bone volume in AR3.6 transgenic mice [176]. Microstructural analysis of cancellous bone by $\mu \mathrm{CT}$ revealed significant loss of bone volume and trabecular number after ORX. Immediate DHT replacement prevented degradation of trabecular bone, particularly in AR transgenic mice, as compared to controls $[23,176]$, suggesting enhanced androgen responsiveness in osteoblasts and osteocytes. Ablating mature osteoblasts' AR decreased bone mass and reduced the number of trabeculae, indicating a shift towards bone resorption $[23,177]$. The decline in trabecular number after ORX in AR transgenic animals was prevented in the state of high turnover, where DHT treatment even increasing the trabecular number [176]. These data show the importance 
of supporting androgen signaling to reduce bone turnover via AR, probably by inhibiting osteoclasts formation or activity via osteocyte-mediated effects.

However, additional knowledge on the roles of AR and ER in bone metabolism stems from research applying cell-specific deletions using the Cre/LoxP technique. Cre/LoxP recombination is a site-specific recombinase (Cre enzymes) technique. Cre recombinase recombines a pair of short target sequences called the LoxP sequences. The technique used to carry out deletions at specific sites. In this context, the global deletion of AR in male mice led to significant alterations, particularly in serum testosterone concentration [22,178]. Therefore, although the volume of cancellous bone and cortical bone of male AR knockout mice is reduced due to an increase in bone resorption, it remains to be clarified if it occurred due to AR loss or rather due to the simultaneous hypogonadism [179]. ARKO mice had reduced bone mass and decreased stiffness, and the effect of AR loss on the bone microstructure of male mice was greater than female mice [26].

While AR deletion in the cells of myeloid/osteoclast lineage did not lead to skeletal abnormalities, the deletion of the AR in osteoprogenitor cells (Prx1(paired-related homeobox gene)-Cre) leads to cancellous bone loss with higher resorption, the effects being more pronounced in males compared to female mice [23]. The findings were similar across Cre models in osteoblast lineage (e.g., Colla1 (type I collagen)-, Ocn(osteocalcin)-, Dmp1(dentin matrix protein 1)-Cre mice crossed with floxed AR mice) $[24,177,180]$. Furthermore, in cancellous bone, these definitive effects of AR signaling in male mice seem inconsistent with the aforementioned human studies that estrogen is a major regulator of bone metabolism in men [179].

\section{Molecular Mechanisms of AR Signaling in Skeletal Stem and Progenitor Cells}

In earlier decades, the therapeutic potential of bone marrow mesenchymal stem/progenitor cells (BMSCs) was recognized, considering their ability to differentiate into osteoblasts and chondroblasts [181,182]. In this sense, BMSC transplantation was able to enhance the formation of new bone through promoted differentiation to osteoblasts and chondrocytes to improve bone-related diseases [183].

It is reported that androgen can enhance osteoblast differentiation and regulate the production and organization of bone matrix, improve the synthesis of extracellular matrix proteins, and stimulate mineralization [35]. Colvard et al. [184] discovered AR expression in cultured osteoblasts. Since then, AR expression was confirmed both in vivo and in vitro in osteoblasts and osteocytes [184,185]. Furthermore, in vitro studies showed AR binding in other bone cell lines (human osteosarcoma, osteoblast-like, and primary osteoblasts from several species) [32,186-194]. In humans, higher AR expression was found in osteoblasts from cortical bone compared to cancellous bone, with no sex-related differences [32,195]. Most studies [187,189,196,197], with some exceptions [32,198], indicated the ability of androgen to up-regulate its own receptor's expression in osteoblasts. In the literature, the relative AR expression was examined during cultured osteoblast differentiation, demonstrating an increase in AR levels from proliferation through differentiation to reach maximum expression in mature mineralizing cultures $[179,199]$.

There is sufficient evidence that osteoblasts are derived from bone marrow pluripotent mesenchymal stem cells. Some articles reported that bone marrow-derived mesenchymal stem cells (BMSCs) express the AR [200-202]. Also, the AR has been detected on megakaryocytes [201,203] and endothelial cells $[201,203,204]$ in the bone compartment. Therefore, mediation of androgen effects on bone may involve other AR expressing cells, apart from osteoblasts and chondrocytes.

Considering BMSCs ability to differentiate into osteoblast lineage cells, they were in focus of investigations of AR signaling. ARKO mice show a reduction in bone formation by effects on osteoblast differentiation and mineralization [31,205]. Indeed, BMSCs had lower expression of osteoblast differentiation-related class genes in ARKO compared to wild type mice, as evidenced in microarray analysis [206]. Our previous study has shown that androgen therapy promotes two important indications for pre-osteoblast differentiation in MC3T3-E1 osteoblast precursor cells 
(alkaline phosphatase activity and calcium deposition), suggesting that androgen therapy on osteoblast differentiation has a positive effect $[207,208]$. Mechanistically, we identified several target genes needed for bone formation mediated by AR, such as TNSALP (the tissue-nonspecific alkaline phosphatase)-encoded alkaline phosphatase 2 (Akp2) gene, SIBLING (the small integrin-binding ligand N-linked glycoprotein) gene family $[207,209]$. Androgen/AR could induce TNSALP and SIBLING gene family expression by binding to the androgen response elements (ARE) motif in their promoter regions [207]. The androgen-enhanced TNSALP expression and activity lead to $\beta$-glycerophosphate hydrolysis increases inorganic phosphate $(\mathrm{Pi})$ levels. The transport of $\mathrm{Pi}$ into the cell results in further stimulation AR expression and mineralization in osteoblasts, which could be inhibited by Pi transporter inhibitors or levamisole, a tissue non-specific alkaline phosphatase (TNAP) activity inhibitor [207]. The regulation of TNSALP and SIBLING gene expression by androgen/AR ensures that sufficient TNSALP activity is obtained on the outer surface of osteoblasts and matrix vesicles to provide sufficient $\mathrm{Pi}$, and SIBLING matrix proteins required for the initial formation of hydroxyapatite crystals during osteoblastic mineralization (Figure 1).

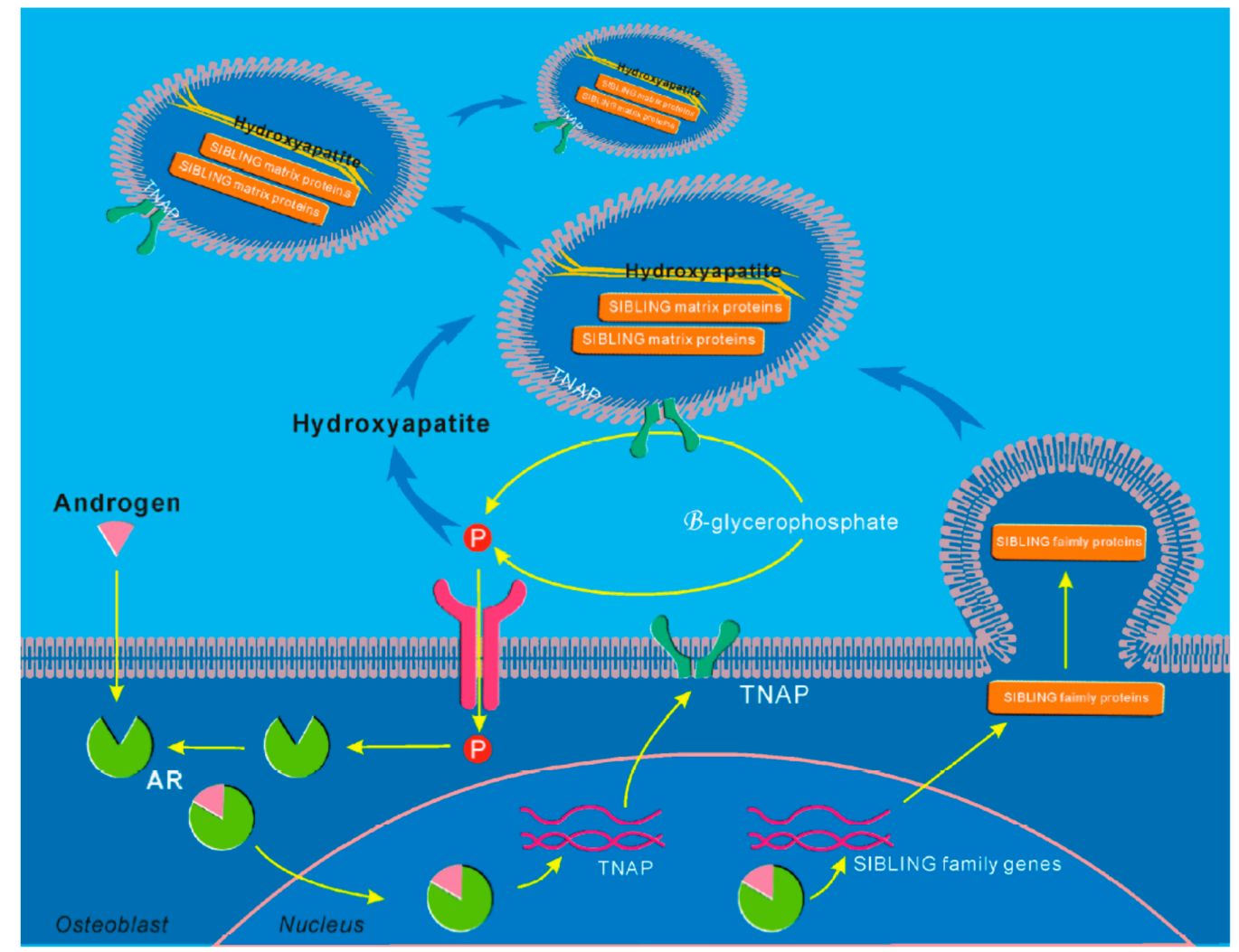

Figure 1. Molecular schemas of androgen/AR actions on osteoblastic mineralization. Androgen/AR induces TNAP and SIBLING family gene expression in osteoblasts by binding to the ARE motif in these

gene promoter regions. The androgen-enhanced TNAP expression and activity results in an increased Pi concentration from the hydrolysis of $\beta$-glycerophosphate. The transport of Pi into the cell results in a further stimulation AR expression and mineralization in osteoblasts. The regulation of TNAP and SIBLING gene expression by androgen and AR ensures that sufficient TNAP activity is available at the outer membrane surface of osteoblasts and matrix vesicles to provide sufficient Pi, and SIBLING matrix proteins required for the initial formation of hydroxyapatite crystals during osteoblastic mineralization. ARE: androgen response elements; TNAP: tissue non-specific alkaline phosphatase; SIBLING: the small integrin-binding ligand N-linked glycoprotein

Early studies have shown that androgen and AR signals inhibit embryonic stem cells' self-renewal process $[210,211]$. Similar results were obtained in ARKO mice, indicating that AR deficiency enhances 
BMSC self-renewal [174,212-214]. Interestingly, it is still not sufficiently understood whether sex affects the self-renewal potential of these stem cells. For example, gender had little effect on self-renewal of BMSCs in one study $[179,215]$, whereas another study demonstrated that the male gender had an inhibitory effect. The production of adipocyte-derived stromal cells (ADSCs) has been shown to have similar characteristics to BMSCs [216]. Importantly, better potential for self-renewal was ascertained in ADSCs and BMSCs isolated from ARKO compared to WT mice [202]. Further mechanistic studies indicate that BMSCs proliferation is promoted in AR deficiency through the activation of AKT and extracellular signal-regulated kinase (Erk)1/2 via increasing the expression of epidermal growth factor receptor (EGFR) [213]. Overall, all evidence suggests an inhibitory potential of androgen/AR signaling for BMSCs self-renewal by indirectly regulating AKT and Erk1/2.

There is a gender difference in adipose accumulation, and it is observed that male adipose tissue is less than female $[217,218]$, indicating that androgen and AR signaling can restrain adipogenesis by inhibiting the function of pre-adipocytes and BMSCs. Here we proposed several molecular pathways of adipogenesis and osteogenesis to be regulated by androgen and AR signaling (Figure 2). Androgens and AR signaling increase expressions of insulin-like growth factor binding protein 3 (IGFBP3), thereby inhibiting the binding of insulin-like growth factor (IGF) to its receptor (IGF-R) [206,219]. IGF-R was required for adipocyte differentiation, and inhibition of IGF-R by androgen treatment results in less adipogenesis [206]. On the other hand, androgen treatments could inhibit expressions of adipogenic markers, such as peroxisome proliferator-activated receptor-gamma 2 (PPAR $\gamma 2$ ), lipoprotein lipase (LPL) and adipocyte protein 2 (aP2), likely through forming AR, $\beta$-catenin, and $\mathrm{T}$ cell factor 4 protein complex $[206,220]$. Together, these findings highlight that androgens/AR can modulate the functions of BMSCs to inhibit adipogenesis and promote osteogenesis. 


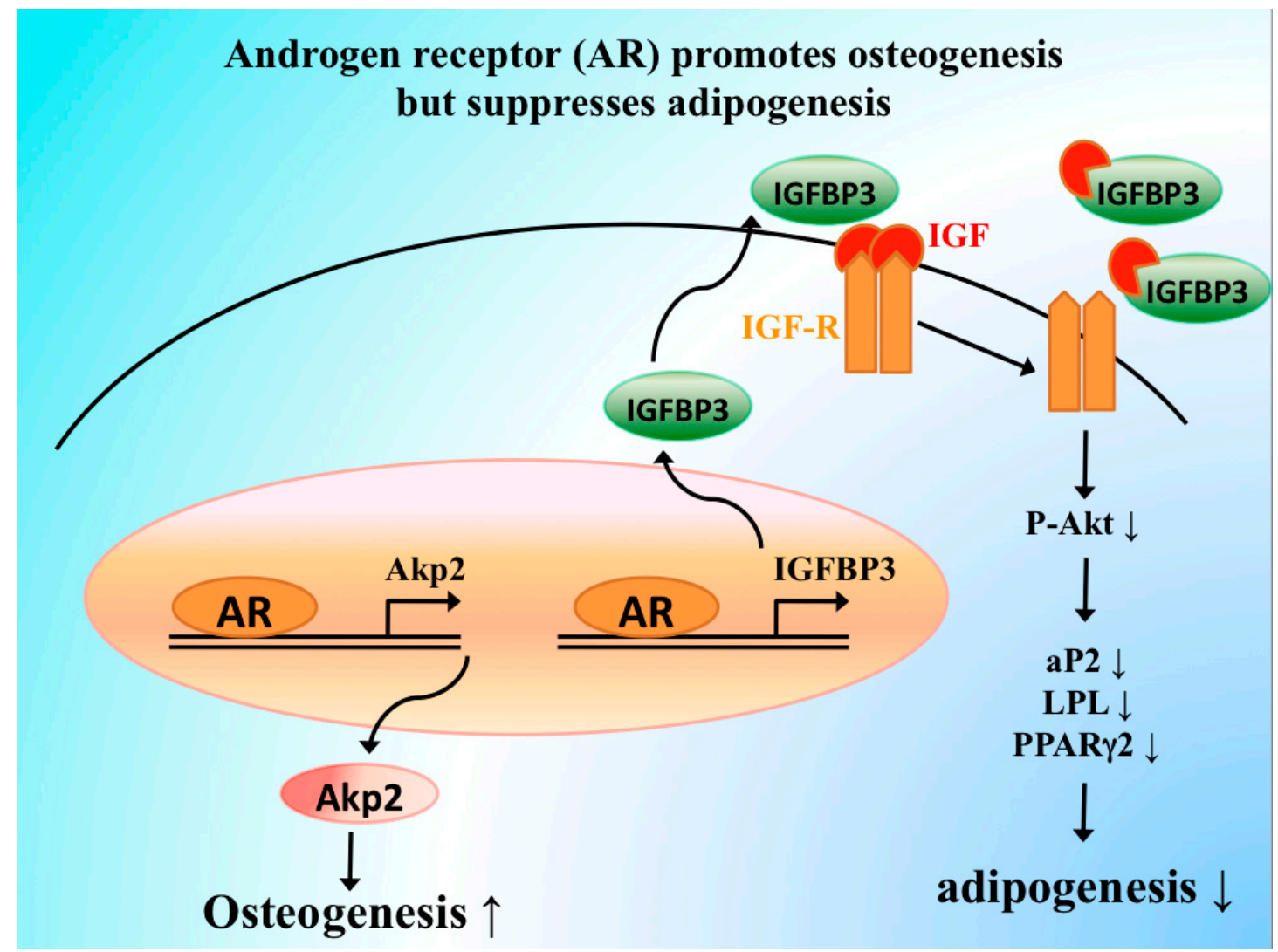

Figure 2. Androgen receptor suppresses adipogenesis but promotes osteogenesis in bone marrow stromal cells. AR increases insulin-like growth factor binding protein 3 (IGFBP3) through direct binding to its promoter region. The IGFBP3 increased by AR then participates in blocking insulin growth factor (IGF) receptor signaling to inhibit AK straining transforming (Akt) activation that leads to a decrease in the expressions of adipogenic markers, such as peroxisome proliferator-activated receptor-gamma 2 (PPAR $\gamma 2$ ), lipoprotein lipase (LPL), and adipocyte protein 2 (aP2), and causes less adipocyte differentiation. On the other hand, AR induces the expression of alkaline phosphatase 2 (Akp2) to promote osteogenesis.

\section{Effects of Androgen Therapy on Bone}

T replacement therapy (TRT) is recommended in hypogonadal men for the maintenance of sex characteristics and corrects androgen deficiency, although prostate cancer risk should be considered in different ages and populations [36]. Hypogonadism men, who are characterized by increased bone turnover and bone loss [100], would also benefit from androgen replacement therapy through suppressing bone resorption [53]. Likewise, androgens in hirsute women preserve bone structure even with low estradiol levels [143]; similarly, bone loss in postmenopausal women could be prevented by androgen therapy [221-225].

Regarding the efficacy of TRT on BMD, the results of data are conflicting. A meta-analysis collecting eight placebo-controlled trials including 365 participants demonstrated that TRT via intramuscular injection was associated with a gain in lumbar BMD, but a non-significant increase in the femoral neck, besides, T therapy via transdermal route had no impacts in this study [226]. T-undecanoate (TU), a long-acting TRT, significantly increases lumbar and femoral neck's BMD after 36 months follow-up in middle-aged, hypogonadal men [48]. In an eight-year-follow up cohort study revealed similar positive effects of TU on the vertebral and femoral BMD [227]. For men with late-onset hypogonadism, TRT resulted in improvement of muscle mass, strength, and BMD, but data about the improvement in fall and fracture remained to be investigated. 
Since the positive effect of $\mathrm{T}$ supplement on promoting bone health is not entirely via its effectiveness, considering that $\mathrm{T}$ could be aromatized to estrogen, which is also a contributor to bone metabolism. It is not clear how much of the $\mathrm{T}$ anabolic effects on bone in older men are from pure testosterone effects and how much derive from aromatization. In an attempt to unravel the relative effects of testosterone vs. estrogen, a study was conducted in which the participators were administered a long-acting GnRH agonist and an aromatase inhibitor. The changes of bone formation and resorption markers followed physiologic $\mathrm{T}$ and $\mathrm{E}$ replacement revealed the role of estrogen as the dominant regulator of bone resorption, while bone formation was maintained by both estrogen and testosterone [228].

Selective androgen receptor modulators (SARMs), similar to selective estrogen receptor modulators (SERMs) or other tissue-selective receptors binding molecules, activate the AR receptors in a tissue-specific manner without undesirable side effects, providing treatment of choice for various diseases, such as osteoporosis, breast cancer or muscular disorders [229]. The arylpropionamide-derived SARM, S-040503, increased BMD and the biomechanical strength of the femoral cortical bone in an animal model with orchiectomized rats, and similar results were also found in postmenopausal osteoporosis animal models with ovariectomized rats [230,231]. Another SARM in clinical trials, Enobosarm (GTx-024; GTx, Memphis, TN, USA), might lead to improvement of lean body mass and muscle wasting in cancer cachexia patients [232,233], but the effects on BMD or fracture need to be further investigated. The agonistic effects of SARM on bone, endothelium, and brain, and antagonistic effects on the prostate, might be equally significant, like SERMs in women. Considering importance of ER in cancellous bone, even older men with osteoporosis could benefit from the administration of SERMs with the appropriate tissue selectivity, while on the other hand, osteoporotic women may find SARMs equally helpful. However, we still need to reach a better understanding of how SARMs modulate the AR signaling and its impact on bone structure and metabolism. In this context, new insights may soon become available through clinical trials, application of new technologies of genetics, and proteomics along with the use of cell-specific transgenic and knockout mice.

\section{Conclusion and Future Perspectives}

There has been a lot of progress in our understanding of estrogen effects on bone, which already led to improved osteoporosis treatment. However, androgen actions on bone remain mostly unknown. Moreover, additional questions are raised through recent discoveries in the field of bone biology and physiology. It is of paramount interest to ensure further progress in the relatively unexplored area and unravel the mechanisms by which androgens affect bone formation and cellular activities.

In the past few years, we realized that androgens are important and required for skeletal health both in men and women, which forced us to rethink the actions of sex steroids in the skeletogenic stem progenitor cells within bone microenvironment and searched the potential treatment for bone injury such as segmental bone defects. The observation that androgens have anabolic effects in bone fracture repair in animals is also relevant for humans and might even help further optimize fracture healing in a clinical context. Based on the observed tissue specificity of SARMs, with a mixture of agonistic and antagonistic effects, the concept of androgens/AR targeted therapy against prostate cancer evolved; the subsequent and ongoing discoveries related to androgen signaling in osteoporosis and bone fracture indicate the potential for improvement of the skeletal stem progenitor cell activities. The ultimate intention of finding an "ideal" androgen that would provide regeneration potential against the major diseases in the bone may become a possibility in the near future.

Author Contributions: Conceptualization-J.-F.C. and H.-Y.K.; Funding acquisition-H.-Y.K.; Investigation-J.-F.C., P.-W.L. and Y.-R.T.; Project Administration-H.-Y.K.; Resources, H.-Y.K.; Supervision-H.-Y.K.; Writing-Original Draft-J.-F.C., H.-Y.K. and Y.-C.Y.; Writing-Review \& Editing-J.-F.C., P.-W.L., Y.-R.T. and H.-Y.K. 
Funding: This study was supported by CMRPD8G0081-3, CMRPD8F0171-3, CMRPG6H0281, and CMRPD8D0071-2 grants from Kaohsiung Chang Gung Memorial Hospital, Taiwan, and by 107-2320-B-182-035-MY3 and 106-2629-B-182A-001-MY3 grants from Ministry of Science and Technology, Taiwan.

Acknowledgments: The authors would like to acknowledge Ko-En Huang for his support in setting up the reproductive medicine laboratory at our department and for his encouragement on developing this review project.

Conflicts of Interest: The authors declare no conflict of interest. The funders had no role in the design of the study; in the collection, analyses, or interpretation of data; in the writing of the manuscript, or in the decision to publish the results.

\section{References}

1. Brown-Sequard, C.E. Note on the effects produced on man by subcutaneous injections of a liquid obtained from the testicles of animals. Lancet 1889, 134, 105-107. [CrossRef]

2. Chang, C.S.; Kokontis, J.; Liao, S.T. Molecular cloning of human and rat complementary DNA encoding androgen receptors. Science 1988, 240, 324-326. [CrossRef] [PubMed]

3. Schmidt, W.N.; Katzenellenbogen, B.S. Androgen-uterine interactions: An assessment of androgen interaction with the testosterone- and estrogen-receptor systems and stimulation of uterine growth and progesterone-receptor synthesis. Mol. Cell. Endocrinol. 1979, 15, 91-108. [CrossRef]

4. Zava, D.T.; McGuire, W.L. Androgen action through estrogen receptor in a human breast cancer cell line. Endocrinology 1978, 103, 624-631. [CrossRef] [PubMed]

5. Moverare, S.; Venken, K.; Eriksson, A.L.; Andersson, N.; Skrtic, S.; Wergedal, J.; Mohan, S.; Salmon, P.; Bouillon, R.; Gustafsson, J.A.; et al. Differential effects on bone of estrogen receptor alpha and androgen receptor activation in orchidectomized adult male mice. Proc. Natl. Acad. Sci. USA 2003, 100, 13573-13578. [CrossRef] [PubMed]

6. Pines, M.; Hurwitz, S. The role of the growth plate in longitudinal bone growth. Poult. Sci. 1991, 70, 1806-1814. [CrossRef]

7. Shulman, D.I.; Francis, G.L.; Palmert, M.R.; Eugster, E.A.; Lawson Wilkins Pediatric Endocrine Society Drug and Therapeutics Committee. Use of aromatase inhibitors in children and adolescents with disorders of growth and adolescent development. Pediatrics 2008, 121, e975-e983. [CrossRef]

8. Cutler, G.B., Jr. The role of estrogen in bone growth and maturation during childhood and adolescence. J. Steroid Biochem. Mol. Biol. 1997, 61, 141-144. [CrossRef]

9. Smith, E.P.; Boyd, J.; Frank, G.R.; Takahashi, H.; Cohen, R.M.; Specker, B.; Williams, T.C.; Lubahn, D.B.; Korach, K.S. Estrogen resistance caused by a mutation in the estrogen-receptor gene in a man. N. Engl. J. Med. 1994, 331, 1056-1061. [CrossRef]

10. Morishima, A.; Grumbach, M.M.; Simpson, E.R.; Fisher, C.; Qin, K. Aromatase deficiency in male and female siblings caused by a novel mutation and the physiological role of estrogens. J. Clin. Endocrinol. Metab. 1995, 80, 3689-3698.

11. Duan, Y.; Turner, C.H.; Kim, B.T.; Seeman, E. Sexual dimorphism in vertebral fragility is more the result of gender differences in age-related bone gain than bone loss. J. Bone Miner. Res. 2001, 16, 2267-2275. [CrossRef] [PubMed]

12. Callewaert, F.; Venken, K.; Kopchick, J.J.; Torcasio, A.; van Lenthe, G.H.; Boonen, S.; Vanderschueren, D. Sexual dimorphism in cortical bone size and strength but not density is determined by independent and time-specific actions of sex steroids and igf-1: Evidence from pubertal mouse models. J. Bone Miner. Res. 2010, 25, 617-626. [CrossRef] [PubMed]

13. Venken, K.; Moverare-Skrtic, S.; Kopchick, J.J.; Coschigano, K.T.; Ohlsson, C.; Boonen, S.; Bouillon, R.; Vanderschueren, D. Impact of androgens, growth hormone, and igf-i on bone and muscle in male mice during puberty. J. Bone Miner. Res. 2007, 22, 72-82. [CrossRef] [PubMed]

14. Lindberg, M.K.; Vandenput, L.; Moverare Skrtic, S.; Vanderschueren, D.; Boonen, S.; Bouillon, R.; Ohlsson, C. Androgens and the skeleton. Miner. Endocrinol. 2005, 30, 15-25.

15. Almeida, M.; Laurent, M.R.; Dubois, V.; Claessens, F.; O’Brien, C.A.; Bouillon, R.; Vanderschueren, D.; Manolagas, S.C. Estrogens and androgens in skeletal physiology and pathophysiology. Physiol. Rev. 2017, 97, 135-187. [CrossRef] 
16. Vanderschueren, D.; Van Herck, E.; Nijs, J.; Ederveen, A.G.; De Coster, R.; Bouillon, R. Aromatase inhibition impairs skeletal modeling and decreases bone mineral density in growing male rats. Endocrinology 1997, 138, 2301-2307. [CrossRef]

17. DiGirolamo, D.J.; Mukherjee, A.; Fulzele, K.; Gan, Y.; Cao, X.; Frank, S.J.; Clemens, T.L. Mode of growth hormone action in osteoblasts. J. Biol. Chem. 2007, 282, 31666-31674. [CrossRef]

18. Kassem, M.; Blum, W.; Ristelli, J.; Mosekilde, L.; Eriksen, E.F. Growth hormone stimulates proliferation and differentiation of normal human osteoblast-like cells in vitro. Calcif. Tissue Int. 1993, 52, 222-226. [CrossRef]

19. Li, H.; Bartold, P.M.; Zhang, C.Z.; Clarkson, R.W.; Young, W.G.; Waters, M.J. Growth hormone and insulin-like growth factor i induce bone morphogenetic proteins 2 and 4: A mediator role in bone and tooth formation? Endocrinology 1998, 139, 3855-3862.

20. Guntur, A.R.; Rosen, C.J. Igf-1 regulation of key signaling pathways in bone. Bonekey Rep. 2013, 2, 437. [CrossRef]

21. Langlois, J.A.; Rosen, C.J.; Visser, M.; Hannan, M.T.; Harris, T.; Wilson, P.W.; Kiel, D.P. Association between insulin-like growth factor $\mathrm{i}$ and bone mineral density in older women and men: The framingham heart study. J. Clin. Endocrinol. Metab. 1998, 83, 4257-4262. [CrossRef] [PubMed]

22. Yeh, S.; Tsai, M.Y.; Xu, Q.; Mu, X.M.; Lardy, H.; Huang, K.E.; Lin, H.; Yeh, S.D.; Altuwaijri, S.; Zhou, X.; et al. Generation and characterization of androgen receptor knockout (arko) mice: An in vivo model for the study of androgen functions in selective tissues. Proc. Natl. Acad. Sci. USA 2002, 99, 13498-13503. [CrossRef] [PubMed]

23. Ucer, S.; Iyer, S.; Bartell, S.M.; Martin-Millan, M.; Han, L.; Kim, H.N.; Weinstein, R.S.; Jilka, R.L.; O’Brien, C.A.; Almeida, M.; et al. The effects of androgens on murine cortical bone do not require ar or eralpha signaling in osteoblasts and osteoclasts. J. Bone Miner. Res. 2015, 30, 1138-1149. [CrossRef] [PubMed]

24. Sinnesael, M.; Claessens, F.; Laurent, M.; Dubois, V.; Boonen, S.; Deboel, L.; Vanderschueren, D. Androgen receptor (ar) in osteocytes is important for the maintenance of male skeletal integrity: Evidence from targeted ar disruption in mouse osteocytes. J. Bone Miner. Res. 2012, 27, 2535-2543. [CrossRef]

25. Weinstein, R.S.; Jilka, R.L.; Parfitt, A.M.; Manolagas, S.C. The effects of androgen deficiency on murine bone remodeling and bone mineral density are mediated via cells of the osteoblastic lineage. Endocrinology 1997, 138, 4013-4021. [CrossRef]

26. Lin, P.W.; Lan, K.C.; Tsai, M.Y.; Shyr, C.R.; Chang, C.; Huang, K.E.; Kang, H.Y. The differential effects of sex hormones on the bone metabolism in mice with androgen receptor deficiency. Adapt. Med. 2018, 10, 143-154. [CrossRef]

27. Fatayerji, D.; Eastell, R. Age-related changes in bone turnover in men. J. Bone Miner. Res. 1999, 14, $1203-1210$. [CrossRef]

28. Meier, C.; Nguyen, T.V.; Center, J.R.; Seibel, M.J.; Eisman, J.A. Bone resorption and osteoporotic fractures in elderly men: The dubbo osteoporosis epidemiology study. J. Bone Miner. Res. 2005, 20, 579-587. [CrossRef]

29. Szulc, P.; Montella, A.; Delmas, P.D. High bone turnover is associated with accelerated bone loss but not with increased fracture risk in men aged 50 and over: The prospective minos study. Ann. Rheum. Dis. 2008, 67, 1249-1255. [CrossRef]

30. Bauer, D.C.; Garnero, P.; Harrison, S.L.; Cauley, J.A.; Eastell, R.; Ensrud, K.E.; Orwoll, E.; Osteoporotic Fractures in Men Research Group. Biochemical markers of bone turnover, hip bone loss, and fracture in older men: The mros study. J. Bone Miner. Res. 2009, 24, 2032-2038. [CrossRef]

31. Sinnesael, M.; Jardi, F.; Deboel, L.; Laurent, M.R.; Dubois, V.; Zajac, J.D.; Davey, R.A.; Carmeliet, G.; Claessens, F.; Vanderschueren, D. The androgen receptor has no direct antiresorptive actions in mouse osteoclasts. Mol. Cell. Endocrinol. 2015, 411, 198-206. [CrossRef] [PubMed]

32. Kasperk, C.; Helmboldt, A.; Borcsok, I.; Heuthe, S.; Cloos, O.; Niethard, F.; Ziegler, R. Skeletal site-dependent expression of the androgen receptor in human osteoblastic cell populations. Calcif. Tissue Int. 1997, 61, 464-473. [CrossRef] [PubMed]

33. Bellido, T.; Jilka, R.L.; Boyce, B.F.; Girasole, G.; Broxmeyer, H.; Dalrymple, S.A.; Murray, R.; Manolagas, S.C. Regulation of interleukin-6, osteoclastogenesis, and bone mass by androgens. The role of the androgen receptor. J. Clin. Investig. 1995, 95, 2886-2895. [CrossRef] [PubMed]

34. Kasperk, C.H.; Wakley, G.K.; Hierl, T.; Ziegler, R. Gonadal and adrenal androgens are potent regulators of human bone cell metabolism in vitro. J. Bone Miner. Res. 1997, 12, 464-471. [CrossRef] 
35. Kasperk, C.H.; Wergedal, J.E.; Farley, J.R.; Linkhart, T.A.; Turner, R.T.; Baylink, D.J. Androgens directly stimulate proliferation of bone cells in vitro. Endocrinology 1989, 124, 1576-1578. [CrossRef] [PubMed]

36. Bhasin, S.; Brito, J.P.; Cunningham, G.R.; Hayes, F.J.; Hodis, H.N.; Matsumoto, A.M.; Snyder, P.J.; Swerdloff, R.S.; Wu, F.C.; Yialamas, M.A. Testosterone therapy in men with hypogonadism: An endocrine society clinical practice guideline. J. Clin. Endocrinol. Metab. 2018, 103, 1715-1744. [CrossRef]

37. Francis, R.M. The effects of testosterone on osteoporosis in men. Clin. Endocrinol. 1999, 50, 411-414. [CrossRef]

38. Finkelstein, J.S.; Neer, R.M.; Biller, B.M.; Crawford, J.D.; Klibanski, A. Osteopenia in men with a history of delayed puberty. N. Engl. J. Med. 1992, 326, 600-604. [CrossRef]

39. Finkelstein, J.S.; Klibanski, A.; Neer, R.M. A longitudinal evaluation of bone mineral density in adult men with histories of delayed puberty. J. Clin. Endocrinol. Metab. 1996, 81, 1152-1155.

40. Benito, M.; Gomberg, B.; Wehrli, F.W.; Weening, R.H.; Zemel, B.; Wright, A.C.; Song, H.K.; Cucchiara, A.; Snyder, P.J. Deterioration of trabecular architecture in hypogonadal men. J. Clin. Endocrinol. Metab. 2003, 88, 1497-1502. [CrossRef]

41. Leifke, E.; Korner, H.C.; Link, T.M.; Behre, H.M.; Peters, P.E.; Nieschlag, E. Effects of testosterone replacement therapy on cortical and trabecular bone mineral density, vertebral body area and paraspinal muscle area in hypogonadal men. Eur. J. Endocrinol. 1998, 138, 51-58. [CrossRef] [PubMed]

42. Mellstrom, D.; Johnell, O.; Ljunggren, O.; Eriksson, A.L.; Lorentzon, M.; Mallmin, H.; Holmberg, A.; Redlund-Johnell, I.; Orwoll, E.; Ohlsson, C. Free testosterone is an independent predictor of bmd and prevalent fractures in elderly men: Mros sweden. J. Bone Miner. Res. 2006, 21, 529-535. [CrossRef] [PubMed]

43. Seeman, E.; Melton, L.J., 3rd; O’Fallon, W.M.; Riggs, B.L. Risk factors for spinal osteoporosis in men. Am. J. Med. 1983, 75, 977-983. [CrossRef]

44. Stanley, H.L.; Schmitt, B.P.; Poses, R.M.; Deiss, W.P. Does hypogonadism contribute to the occurrence of a minimal trauma hip fracture in elderly men? J. Am. Geriatr. Soc. 1991, 39, 766-771. [CrossRef] [PubMed]

45. Behre, H.M.; Kliesch, S.; Leifke, E.; Link, T.M.; Nieschlag, E. Long-term effect of testosterone therapy on bone mineral density in hypogonadal men. J. Clin. Endocrinol. Metab. 1997, 82, 2386-2390. [CrossRef]

46. Lee, M.J.; Ryu, H.K.; An, S.Y.; Jeon, J.Y.; Lee, J.I.; Chung, Y.S. Testosterone replacement and bone mineral density in male pituitary tumor patients. Endocrinol. Metab. 2014, 29, 48-53. [CrossRef]

47. Basurto, L.; Zarate, A.; Gomez, R.; Vargas, C.; Saucedo, R.; Galvan, R. Effect of testosterone therapy on lumbar spine and hip mineral density in elderly men. Aging Male 2008, 11, 140-145. [CrossRef]

48. Aversa, A.; Bruzziches, R.; Francomano, D.; Greco, E.A.; Fornari, R.; Di Luigi, L.; Lenzi, A.; Migliaccio, S. Effects of long-acting testosterone undecanoate on bone mineral density in middle-aged men with late-onset hypogonadism and metabolic syndrome: Results from a 36 months controlled study. Aging Male 2012, 15, 96-102. [CrossRef]

49. Snyder, P.J.; Peachey, H.; Hannoush, P.; Berlin, J.A.; Loh, L.; Holmes, J.H.; Dlewati, A.; Staley, J.; Santanna, J.; Kapoor, S.C.; et al. Effect of testosterone treatment on bone mineral density in men over 65 years of age. J. Clin. Endocrinol. Metab. 1999, 84, 1966-1972. [CrossRef]

50. Haider, A.; Meergans, U.; Traish, A.; Saad, F.; Doros, G.; Lips, P.; Gooren, L. Progressive improvement of $\mathrm{t}$-scores in men with osteoporosis and subnormal serum testosterone levels upon treatment with testosterone over six years. Int. J. Endocrinol. 2014, 2014, 496948. [CrossRef]

51. Jackson, J.A.; Kleerekoper, M.; Parfitt, A.M.; Rao, D.S.; Villanueva, A.R.; Frame, B. Bone histomorphometry in hypogonadal and eugonadal men with spinal osteoporosis. J. Clin. Endocrinol. Metab. 1987, 65, 53-58. [CrossRef] [PubMed]

52. Francis, R.M.; Peacock, M.; Aaron, J.E.; Selby, P.L.; Taylor, G.A.; Thompson, J.; Marshall, D.H.; Horsman, A. Osteoporosis in hypogonadal men: Role of decreased plasma 1,25-dihydroxyvitamin d, calcium malabsorption, and low bone formation. Bone 1986, 7, 261-268. [CrossRef]

53. Baran, D.T.; Bergfeld, M.A.; Teitelbaum, S.L.; Avioli, L.V. Effect of testosterone therapy on bone formation in an osteoporotic hypogonadal male. Calcif. Tissue Res. 1978, 26, 103-106. [CrossRef] [PubMed]

54. Guo, C.Y.; Jones, T.H.; Eastell, R. Treatment of isolated hypogonadotropic hypogonadism effect on bone mineral density and bone turnover. J. Clin. Endocrinol. Metab. 1997, 82, 658-665. [CrossRef]

55. Breuil, V.; Euller-Ziegler, L. Gonadal dysgenesis and bone metabolism. Jt. Bone Spine 2001, 68, 26-33. [CrossRef] 
56. Bojesen, A.; Birkebaek, N.; Kristensen, K.; Heickendorff, L.; Mosekilde, L.; Christiansen, J.S.; Gravholt, C.H. Bone mineral density in klinefelter syndrome is reduced and primarily determined by muscle strength and resorptive markers, but not directly by testosterone. Osteoporos. Int. 2011, 22, 1441-1450. [CrossRef]

57. Rohani, F.; Alai, M.R.; Moradi, S.; Amirkashani, D. Evaluation of near final height in boys with constitutional delay in growth and puberty. Endocr. Connect. 2018, 7, 456-459. [CrossRef]

58. Krupa, B.; Miazgowski, T. Bone mineral density and markers of bone turnover in boys with constitutional delay of growth and puberty. J. Clin. Endocrinol. Metab. 2005, 90, 2828-2830. [CrossRef]

59. Bertelloni, S.; Baroncelli, G.I.; Ferdeghini, M.; Perri, G.; Saggese, G. Normal volumetric bone mineral density and bone turnover in young men with histories of constitutional delay of puberty. J. Clin. Endocrinol. Metab. 1998, 83, 4280-4283. [CrossRef]

60. Ojeda, S.; Lloret, M.; Naranjo, A.; Deniz, F.; Chesa, N.; Dominguez, C.; Lara, P.C. Androgen deprivation in prostate cancer and the long-term risk of fracture. Actas Urol. Esp. 2017, 41, 491-496. [CrossRef]

61. Lee, C.H.; Huang, G.; Chan, P.H.; Hai, J.; Yeung, C.Y.; Fong, C.H.; Woo, Y.C.; Ho, K.L.; Yiu, M.K.; Leung, F.; et al. Androgen deprivation therapy and fracture risk in chinese patients with prostate carcinoma. PLoS ONE 2017, 12, e0171495. [CrossRef] [PubMed]

62. Ahmadi, H.; Daneshmand, S. Androgen deprivation therapy: Evidence-based management of side effects. BJU Int. 2013, 111, 543-548. [CrossRef] [PubMed]

63. Warming, L.; Hassager, C.; Christiansen, C. Changes in bone mineral density with age in men and women: A longitudinal study. Osteoporos. Int. 2002, 13, 105-112. [CrossRef] [PubMed]

64. Hughes, I.A.; Davies, J.D.; Bunch, T.I.; Pasterski, V.; Mastroyannopoulou, K.; MacDougall, J. Androgen insensitivity syndrome. Lancet 2012, 380, 1419-1428. [CrossRef]

65. Danilovic, D.L.; Correa, P.H.; Costa, E.M.; Melo, K.F.; Mendonca, B.B.; Arnhold, I.J. Height and bone mineral density in androgen insensitivity syndrome with mutations in the androgen receptor gene. Osteoporos. Int. 2007, 18, 369-374. [CrossRef]

66. Frank, G.R. Role of estrogen and androgen in pubertal skeletal physiology. Med. Pediatr. Oncol. 2003, 41, 217-221. [CrossRef]

67. Ganie, M.A.; Chakraborty, S.; Sehgal, A.; Sreejith, M.; Kandasamy, D.; Jana, M.; Rashid, A. Bone mineral density is unaltered in women with polycystic ovary syndrome. Horm. Metab. Res. 2018, 50, 754-760. [CrossRef]

68. Katulski, K.; Slawek, S.; Czyzyk, A.; Podfigurna-Stopa, A.; Paczkowska, K.; Ignaszak, N.; Podkowa, N.; Meczekalski, B. Bone mineral density in women with polycystic ovary syndrome. J. Endocrinol. Investig. 2014, 37, 1219-1224. [CrossRef]

69. Yang, H.Y.; Lee, H.S.; Huang, W.T.; Chen, M.J.; Chen, S.C.; Hsu, Y.H. Increased risk of fractures in patients with polycystic ovary syndrome: A nationwide population-based retrospective cohort study. J. Bone Miner. Metab. 2018, 36, 741-748. [CrossRef]

70. Rubin, K.H.; Glintborg, D.; Nybo, M.; Andersen, M.; Abrahamsen, B. Fracture risk is decreased in women with polycystic ovary syndrome: A register-based and population-based cohort study. J. Bone Miner. Res. 2016, 31, 709-717. [CrossRef]

71. Finkelstein, J.S.; Klibanski, A.; Neer, R.M.; Greenspan, S.L.; Rosenthal, D.I.; Crowley, W.F., Jr. Osteoporosis in men with idiopathic hypogonadotropic hypogonadism. Ann. Intern. Med. 1987, 106, 354-361. [CrossRef] [PubMed]

72. Finkelstein, J.S.; Klibanski, A.; Neer, R.M.; Doppelt, S.H.; Rosenthal, D.I.; Segre, G.V.; Crowley, W.F., Jr. Increases in bone density during treatment of men with idiopathic hypogonadotropic hypogonadism. J. Clin. Endocrinol. Metab. 1989, 69, 776-783. [CrossRef] [PubMed]

73. Greenspan, S.L.; Neer, R.M.; Ridgway, E.C.; Klibanski, A. Osteoporosis in men with hyperprolactinemic hypogonadism. Ann. Intern. Med. 1986, 104, 777-782. [CrossRef] [PubMed]

74. Greenspan, S.L.; Oppenheim, D.S.; Klibanski, A. Importance of gonadal steroids to bone mass in men with hyperprolactinemic hypogonadism. Ann. Intern. Med. 1989, 110, 526-531. [CrossRef] [PubMed]

75. Klinefelter, H.F., Jr.; Reifenstein, E.C., Jr.; Albright, F., Jr. Syndrome characterized by gynecomastia, aspermatogenesis without a-leydigism, and increased excretion of follicle-stimulating hormone. J. Clin. Endocrinol. Metab. 1942, 2, 615. [CrossRef] 
76. Stagi, S.; Di Tommaso, M.; Manoni, C.; Scalini, P.; Chiarelli, F.; Verrotti, A.; Lapi, E.; Giglio, S.; Dosa, L.; De Martino, M. Bone mineral status in children and adolescents with klinefelter syndrome. Int. J. Endocrinol. 2016, 2016, 3032759. [CrossRef]

77. Bojesen, A.; Juul, S.; Birkebaek, N.; Gravholt, C.H. Increased mortality in klinefelter syndrome. J. Clin. Endocrinol. Metab. 2004, 89, 3830-3834. [CrossRef]

78. Bojesen, A.; Juul, S.; Birkebaek, N.H.; Gravholt, C.H. Morbidity in klinefelter syndrome: A danish register study based on hospital discharge diagnoses. J. Clin. Endocrinol. Metab. 2006, 91, 1254-1260. [CrossRef]

79. Swerdlow, A.J.; Higgins, C.D.; Schoemaker, M.J.; Wright, A.F.; Jacobs, P.A.; United Kingdom Clinical Cytogenetics Group. Mortality in patients with klinefelter syndrome in britain: A cohort study. J. Clin. Endocrinol. Metab. 2005, 90, 6516-6522. [CrossRef]

80. Kubler, A.; Schulz, G.; Cordes, U.; Beyer, J.; Krause, U. The influence of testosterone substitution on bone mineral density in patients with klinefelter's syndrome. Exp. Clin. Endocrinol. 1992, 100, 129-132. [CrossRef]

81. Tahani, N.; Nieddu, L.; Prossomariti, G.; Spaziani, M.; Granato, S.; Carlomagno, F.; Anzuini, A.; Lenzi, A.; Radicioni, A.F.; Romagnoli, E. Long-term effect of testosterone replacement therapy on bone in hypogonadal men with klinefelter syndrome. Endocrine 2018, 61, 327-335. [CrossRef] [PubMed]

82. Wong, F.H.; Pun, K.K.; Wang, C. Loss of bone mass in patients with klinefelter's syndrome despite sufficient testosterone replacement. Osteoporos. Int. 1993, 3, 3-7. [CrossRef]

83. Van den Bergh, J.P.; Hermus, A.R.; Spruyt, A.I.; Sweep, C.G.; Corstens, F.H.; Smals, A.G. Bone mineral density and quantitative ultrasound parameters in patients with klinefelter's syndrome after long-term testosterone substitution. Osteoporos. Int. 2001, 12, 55-62. [CrossRef] [PubMed]

84. Ferlin, A.; Schipilliti, M.; Vinanzi, C.; Garolla, A.; Di Mambro, A.; Selice, R.; Lenzi, A.; Foresta, C. Bone mass in subjects with klinefelter syndrome: Role of testosterone levels and androgen receptor gene cag polymorphism. J. Clin. Endocrinol. Metab. 2011, 96, E739-E745. [CrossRef]

85. Luisetto, G.; Mastrogiacomo, I.; Bonanni, G.; Pozzan, G.; Botteon, S.; Tizian, L.; Galuppo, P. Bone mass and mineral metabolism in klinefelter's syndrome. Osteoporos. Int. 1995, 5, 455-461. [CrossRef] [PubMed]

86. Horowitz, M.; Wishart, J.M.; O'Loughlin, P.D.; Morris, H.A.; Need, A.G.; Nordin, B.E. Osteoporosis and klinefelter's syndrome. Clin. Endocrinol. 1992, 36, 113-118. [CrossRef]

87. Zerbini, C.A.F.; Clark, P.; Mendez-Sanchez, L.; Pereira, R.M.R.; Messina, O.D.; Una, C.R.; Adachi, J.D.; Lems, W.F.; Cooper, C.; Lane, N.E.; et al. Biologic therapies and bone loss in rheumatoid arthritis. Osteoporos. Int. 2017, 28, 429-446. [CrossRef] [PubMed]

88. Bertelloni, S.; Baroncelli, G.I.; Battini, R.; Perri, G.; Saggese, G. Short-term effect of testosterone treatment on reduced bone density in boys with constitutional delay of puberty. J. Bone Miner. Res. 1995, 10, 1488-1495. [CrossRef]

89. Mauras, N.; Haymond, M.W.; Darmaun, D.; Vieira, N.E.; Abrams, S.A.; Yergey, A.L. Calcium and protein kinetics in prepubertal boys. Positive effects of testosterone. J. Clin. Investig. 1994, 93, 1014-1019. [CrossRef]

90. Allen, D.B.; Cuttler, L. Clinical practice. Short stature in childhood-challenges and choices. N. Engl. J. Med. 2013, 368, 1220-1228. [CrossRef]

91. Joss, E.E.; Schmidt, H.A.; Zuppinger, K.A. Oxandrolone in constitutionally delayed growth, a longitudinal study up to final height. J. Clin. Endocrinol. Metab. 1989, 69, 1109-1115. [CrossRef] [PubMed]

92. Wilson, D.M.; McCauley, E.; Brown, D.R.; Dudley, R. Oxandrolone therapy in constitutionally delayed growth and puberty. Bio-technology general corporation cooperative study group. Pediatrics 1995, 96, 1095-1100. [PubMed]

93. Smith, M.R. Osteoporosis during androgen deprivation therapy for prostate cancer. Urology 2002, 60, 79-85. [CrossRef]

94. Poulsen, M.H.; Frost, M.; Abrahamsen, B.; Gerke, O.; Walter, S.; Lund, L. Osteoporosis and prostate cancer; a 24-month prospective observational study during androgen deprivation therapy. Scand. J. Urol. 2019, 53, 34-39. [CrossRef]

95. Kim, D.K.; Lee, J.Y.; Kim, K.J.; Hong, N.; Kim, J.W.; Hah, Y.S.; Koo, K.C.; Kim, J.H.; Cho, K.S. Effect of androgen-deprivation therapy on bone mineral density in patients with prostate cancer: A systematic review and meta-analysis. J. Clin. Med. 2019, 8, 113. [CrossRef]

96. Smith, M.R.; McGovern, F.J.; Fallon, M.A.; Schoenfeld, D.; Kantoff, P.W.; Finkelstein, J.S. Low bone mineral density in hormone-naive men with prostate carcinoma. Cancer 2001, 91, 2238-2245. [CrossRef] 
97. Shahinian, V.B.; Kuo, Y.F.; Freeman, J.L.; Goodwin, J.S. Risk of fracture after androgen deprivation for prostate cancer. N. Engl. J. Med. 2005, 352, 154-164. [CrossRef]

98. Smith, M.R.; Lee, W.C.; Brandman, J.; Wang, Q.; Botteman, M.; Pashos, C.L. Gonadotropin-releasing hormone agonists and fracture risk: A claims-based cohort study of men with nonmetastatic prostate cancer. J. Clin. Oncol. 2005, 23, 7897-7903. [CrossRef]

99. Smith, M.R.; Boyce, S.P.; Moyneur, E.; Duh, M.S.; Raut, M.K.; Brandman, J. Risk of clinical fractures after gonadotropin-releasing hormone agonist therapy for prostate cancer. J. Urol. 2006, 175, 136-139. [CrossRef]

100. Stoch, S.A.; Parker, R.A.; Chen, L.; Bubley, G.; Ko, Y.J.; Vincelette, A.; Greenspan, S.L. Bone loss in men with prostate cancer treated with gonadotropin-releasing hormone agonists. J. Clin. Endocrinol. Metab. 2001, 86, 2787-2791. [CrossRef]

101. Berruti, A.; Dogliotti, L.; Terrone, C.; Cerutti, S.; Isaia, G.; Tarabuzzi, R.; Reimondo, G.; Mari, M.; Ardissone, P.; De Luca, S.; et al. Changes in bone mineral density, lean body mass and fat content as measured by dual energy x-ray absorptiometry in patients with prostate cancer without apparent bone metastases given androgen deprivation therapy. J. Urol. 2002, 167, 2361-2367. [CrossRef]

102. Smith, M.R.; Finkelstein, J.S.; McGovern, F.J.; Zietman, A.L.; Fallon, M.A.; Schoenfeld, D.A.; Kantoff, P.W. Changes in body composition during androgen deprivation therapy for prostate cancer. J. Clin. Endocrinol. Metab. 2002, 87, 599-603. [CrossRef] [PubMed]

103. Zebaze, R.M.; Ghasem-Zadeh, A.; Bohte, A.; Iuliano-Burns, S.; Mirams, M.; Price, R.I.; Mackie, E.J.; Seeman, E. Intracortical remodelling and porosity in the distal radius and post-mortem femurs of women: A cross-sectional study. Lancet 2010, 375, 1729-1736. [CrossRef]

104. Christiansen, B.A.; Kopperdahl, D.L.; Kiel, D.P.; Keaveny, T.M.; Bouxsein, M.L. Mechanical contributions of the cortical and trabecular compartments contribute to differences in age-related changes in vertebral body strength in men and women assessed by qct-based finite element analysis. J. Bone Miner. Res. 2011, 26, 974-983. [CrossRef] [PubMed]

105. Diamond, T.; Campbell, J.; Bryant, C.; Lynch, W. The effect of combined androgen blockade on bone turnover and bone mineral densities in men treated for prostate carcinoma: Longitudinal evaluation and response to intermittent cyclic etidronate therapy. Cancer 1998, 83, 1561-1566. [CrossRef]

106. Smith, M.R.; McGovern, F.J.; Zietman, A.L.; Fallon, M.A.; Hayden, D.L.; Schoenfeld, D.A.; Kantoff, P.W.; Finkelstein, J.S. Pamidronate to prevent bone loss during androgen-deprivation therapy for prostate cancer. N. Engl. J. Med. 2001, 345, 948-955. [CrossRef]

107. Smith, M.R.; Eastham, J.; Gleason, D.M.; Shasha, D.; Tchekmedyian, S.; Zinner, N. Randomized controlled trial of zoledronic acid to prevent bone loss in men receiving androgen deprivation therapy for nonmetastatic prostate cancer. J. Urol. 2003, 169, 2008-2012. [CrossRef]

108. Dunn, J.F.; Nisula, B.C.; Rodbard, D. Transport of steroid hormones: Binding of 21 endogenous steroids to both testosterone-binding globulin and corticosteroid-binding globulin in human plasma. J. Clin. Endocrinol. Metab. 1981, 53, 58-68. [CrossRef]

109. Roy, T.A.; Blackman, M.R.; Harman, S.M.; Tobin, J.D.; Schrager, M.; Metter, E.J. Interrelationships of serum testosterone and free testosterone index with $\mathrm{fm}$ and strength in aging men. Am. J. Physiol. Endocrinol. Metab. 2002, 283, E284-E294. [CrossRef]

110. Khosla, S.; Melton, L.J., 3rd; Atkinson, E.J.; O’Fallon, W.M.; Klee, G.G.; Riggs, B.L. Relationship of serum sex steroid levels and bone turnover markers with bone mineral density in men and women: A key role for bioavailable estrogen. J. Clin. Endocrinol. Metab. 1998, 83, 2266-2274.

111. Feldman, H.A.; Longcope, C.; Derby, C.A.; Johannes, C.B.; Araujo, A.B.; Coviello, A.D.; Bremner, W.J.; McKinlay, J.B. Age trends in the level of serum testosterone and other hormones in middle-aged men: Longitudinal results from the massachusetts male aging study. J. Clin. Endocrinol. Metab. 2002, 87, 589-598. [CrossRef] [PubMed]

112. Bhasin, S.; Pencina, M.; Jasuja, G.K.; Travison, T.G.; Coviello, A.; Orwoll, E.; Wang, P.Y.; Nielson, C.; Wu, F.; Tajar, A.; et al. Reference ranges for testosterone in men generated using liquid chromatography tandem mass spectrometry in a community-based sample of healthy nonobese young men in the framingham heart study and applied to three geographically distinct cohorts. J. Clin. Endocrinol. Metab. 2011, 96, 2430-2439. [CrossRef] [PubMed] 
113. Wu, F.C.; Tajar, A.; Beynon, J.M.; Pye, S.R.; Silman, A.J.; Finn, J.D.; O’Neill, T.W.; Bartfai, G.; Casanueva, F.F.; Forti, G.; et al. Identification of late-onset hypogonadism in middle-aged and elderly men. N. Engl. J. Med. 2010, 363, 123-135. [CrossRef] [PubMed]

114. Orwoll, E.; Blank, J.B.; Barrett-Connor, E.; Cauley, J.; Cummings, S.; Ensrud, K.; Lewis, C.; Cawthon, P.M.; Marcus, R.; Marshall, L.M.; et al. Design and baseline characteristics of the osteoporotic fractures in men (mros) study-A large observational study of the determinants of fracture in older men. Contemp. Clin. Trials 2005, 26, 569-585. [CrossRef]

115. Travison, T.G.; Vesper, H.W.; Orwoll, E.; Wu, F.; Kaufman, J.M.; Wang, Y.; Lapauw, B.; Fiers, T.; Matsumoto, A.M.; Bhasin, S. Harmonized reference ranges for circulating testosterone levels in men of four cohort studies in the united states and europe. J. Clin. Endocrinol. Metab. 2017, 102, 1161-1173. [CrossRef]

116. Mellstrom, D.; Vandenput, L.; Mallmin, H.; Holmberg, A.H.; Lorentzon, M.; Oden, A.; Johansson, H.; Orwoll, E.S.; Labrie, F.; Karlsson, M.K.; et al. Older men with low serum estradiol and high serum shbg have an increased risk of fractures. J. Bone Miner. Res. 2008, 23, 1552-1560. [CrossRef]

117. Meier, C.; Nguyen, T.V.; Handelsman, D.J.; Schindler, C.; Kushnir, M.M.; Rockwood, A.L.; Meikle, A.W.; Center, J.R.; Eisman, J.A.; Seibel, M.J. Endogenous sex hormones and incident fracture risk in older men: The dubbo osteoporosis epidemiology study. Arch. Intern. Med. 2008, 168, 47-54. [CrossRef]

118. Boonen, S.; Vanderschueren, D.; Cheng, X.G.; Verbeke, G.; Dequeker, J.; Geusens, P.; Broos, P.; Bouillon, R. Age-related (type ii) femoral neck osteoporosis in men: Biochemical evidence for both hypovitaminosis dand androgen deficiency-induced bone resorption. J. Bone Miner. Res. 1997, 12, 2119-2126. [CrossRef]

119. Ucer, S.; Iyer, S.; Kim, H.N.; Han, L.; Rutlen, C.; Allison, K.; Thostenson, J.D.; De Cabo, R.; Jilka, R.L.; O'Brien, C.; et al. The effects of aging and sex steroid deficiency on the murine skeleton are independent and mechanistically distinct. J. Bone Miner. Res. 2017, 32, 560-574. [CrossRef]

120. Labrie, F.; Belanger, A.; Cusan, L.; Gomez, J.L.; Candas, B. Marked decline in serum concentrations of adrenal c19 sex steroid precursors and conjugated androgen metabolites during aging. J. Clin. Endocrinol. Metab. 1997, 82, 2396-2402. [CrossRef]

121. Gurnell, E.M.; Chatterjee, V.K. Dehydroepiandrosterone replacement therapy. Eur. J. Endocrinol. 2001, 145, 103-106. [CrossRef]

122. Greendale, G.A.; Edelstein, S.; Barrett-Connor, E. Endogenous sex steroids and bone mineral density in older women and men: The rancho bernardo study. J. Bone Miner. Res. 1997, 12, 1833-1843. [CrossRef] [PubMed]

123. Barrett-Connor, E.; Kritz-Silverstein, D.; Edelstein, S.L. A prospective study of dehydroepiandrosterone sulfate (dheas) and bone mineral density in older men and women. Am. J. Epidemiol. 1993, 137, 201-206. [CrossRef] [PubMed]

124. Mendoza, N.; Motos, M.A. Androgen insensitivity syndrome. Gynecol. Endocrinol. 2013, 29, 1-5. [CrossRef] [PubMed]

125. Gottlieb, B.; Trifiro, M.A. Androgen insensitivity syndrome. In Genereviews@; Adam, M.P., Ardinger, H.H., Pagon, R.A., Wallace, S.E., Bean, L.J.H., Stephens, K., Amemiya, A., Eds.; University of Washington: Seattle, WA, USA, 1993.

126. Bertelloni, S.; Baroncelli, G.I.; Mora, S. Bone health in disorders of sex differentiation. Sex. Dev. 2010, 4, 270-284. [CrossRef]

127. Bertelloni, S.; Meriggiola, M.C.; Dati, E.; Balsamo, A.; Baroncelli, G.I. Bone mineral density in women living with complete androgen insensitivity syndrome and intact testes or removed gonads. Sex. Dev. 2017, 11, 182-189. [CrossRef] [PubMed]

128. Han, T.S.; Goswami, D.; Trikudanathan, S.; Creighton, S.M.; Conway, G.S. Comparison of bone mineral density and body proportions between women with complete androgen insensitivity syndrome and women with gonadal dysgenesis. Eur. J. Endocrinol. 2008, 159, 179-185. [CrossRef] [PubMed]

129. Chin, V.L.; Sheffer-Babila, S.; Lee, T.A.; Tanaka, K.; Zhou, P. A case of complete androgen insensitivity syndrome with a novel androgen receptor mutation. J. Pediatr. Endocrinol. Metab. 2012, 25, 1145-1151. [CrossRef]

130. King, T.F.J.; Wat, W.Z.M.; Creighton, S.M.; Conway, G.S. Bone mineral density in complete androgen insensitivity syndrome and the timing of gonadectomy. Clin. Endocrinol. 2017, 87, 136-140. [CrossRef]

131. Callewaert, F.; Boonen, S.; Vanderschueren, D. Sex steroids and the male skeleton: A tale of two hormones. Trends Endocrinol. Metab. 2010, 21, 89-95. [CrossRef] 
132. Vanderschueren, D.; Vandenput, L.; Boonen, S.; Lindberg, M.K.; Bouillon, R.; Ohlsson, C. Androgens and bone. Endocr. Rev. 2004, 25, 389-425. [CrossRef] [PubMed]

133. Taes, Y.; Lapauw, B.; Vandewalle, S.; Zmierczak, H.; Goemaere, S.; Vanderschueren, D.; Kaufman, J.M.; $\mathrm{T}^{\prime}$ Sjoen, $\mathrm{G}$. Estrogen-specific action on bone geometry and volumetric bone density: Longitudinal observations in an adult with complete androgen insensitivity. Bone 2009, 45, 392-397. [CrossRef] [PubMed]

134. Marcus, R.; Leary, D.; Schneider, D.L.; Shane, E.; Favus, M.; Quigley, C.A. The contribution of testosterone to skeletal development and maintenance: Lessons from the androgen insensitivity syndrome. J. Clin. Endocrinol. Metab. 2000, 85, 1032-1037. [CrossRef] [PubMed]

135. NIH Consensus Development Panel on Osteoporosis Prevention, Diagnosis, and Therapy. Osteoporosis prevention, diagnosis, and therapy. JAMA 2001, 285, 785-795. [CrossRef] [PubMed]

136. Warne, G.L.; Grover, S.; Zajac, J.D. Hormonal therapies for individuals with intersex conditions: Protocol for use. Treat. Endocrinol. 2005, 4, 19-29. [CrossRef]

137. Zborowski, J.V.; Cauley, J.A.; Talbott, E.O.; Guzick, D.S.; Winters, S.J. Clinical review 116: Bone mineral density, androgens, and the polycystic ovary: The complex and controversial issue of androgenic influence in female bone. J. Clin. Endocrinol. Metab. 2000, 85, 3496-3506. [CrossRef]

138. Lingaiah, S.; Morin-Papunen, L.; Piltonen, T.; Puurunen, J.; Sundstrom-Poromaa, I.; Stener-Victorin, E.; Bloigu, R.; Risteli, J.; Tapanainen, J.S. Bone markers in polycystic ovary syndrome: A multicentre study. Clin. Endocrinol. 2017, 87, 673-679. [CrossRef]

139. Karadag, C.; Yoldemir, T.; Gogas Yavuz, D. Determinants of low bone mineral density in premenopausal polycystic ovary syndrome patients. Gynecol. Endocrinol. 2017, 33, 234-237. [CrossRef]

140. Noyan, V.; Yucel, A.; Sagsoz, N. The association of bone mineral density with insulin resistance in patients with polycystic ovary syndrome. Eur. J. Obstet. Gynecol. Reprod. Biol. 2004, 115, 200-205. [CrossRef]

141. Krishnan, A.; Muthusami, S. Hormonal alterations in pcos and its influence on bone metabolism. J. Endocrinol. 2017, 232, R99-R113. [CrossRef]

142. Sawalha, A.H.; Kovats, S. Dehydroepiandrosterone in systemic lupus erythematosus. Curr. Rheumatol. Rep. 2008, 10, 286-291. [CrossRef] [PubMed]

143. Dixon, J.E.; Rodin, A.; Murby, B.; Chapman, M.G.; Fogelman, I. Bone mass in hirsute women with androgen excess. Clin. Endocrinol. 1989, 30, 271-277. [CrossRef] [PubMed]

144. Dagogo-Jack, S.; Al-Ali, N.; Qurttom, M. Augmentation of bone mineral density in hirsute women. J. Clin. Endocrinol. Metab. 1997, 82, 2821-2825. [CrossRef] [PubMed]

145. Piovezan, J.M.; Premaor, M.O.; Comim, F.V. Negative impact of polycystic ovary syndrome on bone health: A systematic review and meta-analysis. Hum. Reprod. Update 2019, 25, 633-645. [CrossRef]

146. Thrailkill, K.M.; Lumpkin, C.K., Jr.; Bunn, R.C.; Kemp, S.F.; Fowlkes, J.L. Is insulin an anabolic agent in bone? Dissecting the diabetic bone for clues. Am. J. Physiol. Endocrinol. Metab. 2005, 289, E735-E745. [CrossRef]

147. Diamanti-Kandarakis, E.; Dunaif, A. Insulin resistance and the polycystic ovary syndrome revisited: An update on mechanisms and implications. Endocr. Rev. 2012, 33, 981-1030. [CrossRef]

148. Cassar, S.; Misso, M.L.; Hopkins, W.G.; Shaw, C.S.; Teede, H.J.; Stepto, N.K. Insulin resistance in polycystic ovary syndrome: A systematic review and meta-analysis of euglycaemic-hyperinsulinaemic clamp studies. Hum. Reprod. 2016, 31, 2619-2631. [CrossRef]

149. Nestler, J.E.; Powers, L.P.; Matt, D.W.; Steingold, K.A.; Plymate, S.R.; Rittmaster, R.S.; Clore, J.N.; Blackard, W.G. A direct effect of hyperinsulinemia on serum sex hormone-binding globulin levels in obese women with the polycystic ovary syndrome. J. Clin. Endocrinol. Metab. 1991, 72, 83-89. [CrossRef]

150. Simberg, N.; Tiitinen, A.; Silfvast, A.; Viinikka, L.; Ylikorkala, O. High bone density in hyperandrogenic women: Effect of gonadotropin-releasing hormone agonist alone or in conjunction with estrogen-progestin replacement. J. Clin. Endocrinol. Metab. 1996, 81, 646-651.

151. Moghetti, P.; Castello, R.; Zamberlan, N.; Rossini, M.; Gatti, D.; Negri, C.; Tosi, F.; Muggeo, M.; Adami, S. Spironolactone, but not flutamide, administration prevents bone loss in hyperandrogenic women treated with gonadotropin-releasing hormone agonist. J. Clin. Endocrinol. Metab. 1999, 84, 1250-1254.

152. Prezelj, J.; Kocijancic, A. Antiandrogen treatment with spironolactone and linestrenol decreases bone mineral density in eumenorrhoeic women with androgen excess. Horm. Metab. Res. 1994, 26, 46-48. [CrossRef] [PubMed] 
153. Bertelloni, S.; Baroncelli, G.I.; Sorrentino, M.C.; Costa, S.; Battini, R.; Saggese, G. Androgen-receptor blockade does not impair bone mineral density in adolescent females. Calcif. Tissue Int. 1997, 61, 1-5. [CrossRef] [PubMed]

154. Lingaiah, S.; Morin-Papunen, L.; Risteli, J.; Tapanainen, J.S. Metformin decreases bone turnover markers in polycystic ovary syndrome: A post hoc study. Fertil. Steril. 2019, 112, 362-370. [CrossRef] [PubMed]

155. Cooke, P.S.; Nanjappa, M.K.; Ko, C.; Prins, G.S.; Hess, R.A. Estrogens in male physiology. Physiol. Rev. 2017, 97, 995-1043. [CrossRef]

156. Vandenput, L.; Ederveen, A.G.; Erben, R.G.; Stahr, K.; Swinnen, J.V.; Van Herck, E.; Verstuyf, A.; Boonen, S.; Bouillon, R.; Vanderschueren, D. Testosterone prevents orchidectomy-induced bone loss in estrogen receptor-alpha knockout mice. Biochem. Biophys. Res. Commun. 2001, 285, 70-76. [CrossRef]

157. Broulik, P.D. Tamoxifen prevents bone loss in castrated male mice. Horm. Metab. Res. 2000, 32, 181-184. [CrossRef]

158. Daci, E.; Verstuyf, A.; Moermans, K.; Bouillon, R.; Carmeliet, G. Mice lacking the plasminogen activator inhibitor 1 are protected from trabecular bone loss induced by estrogen deficiency. J. Bone Miner. Res. 2000, 15, 1510-1516. [CrossRef]

159. Bain, S.D.; Bailey, M.C.; Celino, D.L.; Lantry, M.M.; Edwards, M.W. High-dose estrogen inhibits bone resorption and stimulates bone formation in the ovariectomized mouse. J. Bone Miner. Res. 1993, 8, 435-442. [CrossRef]

160. Onoe, Y.; Miyaura, C.; Ito, M.; Ohta, H.; Nozawa, S.; Suda, T. Comparative effects of estrogen and raloxifene on b lymphopoiesis and bone loss induced by sex steroid deficiency in mice. J. Bone Miner. Res. 2000, 15, 541-549. [CrossRef]

161. Poli, V.; Balena, R.; Fattori, E.; Markatos, A.; Yamamoto, M.; Tanaka, H.; Ciliberto, G.; Rodan, G.A.; Costantini, F. Interleukin-6 deficient mice are protected from bone loss caused by estrogen depletion. EMBO J. 1994, 13, 1189-1196. [CrossRef]

162. Lindberg, M.K.; Moverare, S.; Skrtic, S.; Alatalo, S.; Halleen, J.; Mohan, S.; Gustafsson, J.A.; Ohlsson, C. Two different pathways for the maintenance of trabecular bone in adult male mice. J. Bone Miner. Res. 2002, 17, 555-562. [CrossRef] [PubMed]

163. Vandenput, L.; Boonen, S.; Van Herck, E.; Swinnen, J.V.; Bouillon, R.; Vanderschueren, D. Evidence from the aged orchidectomized male rat model that 17 beta-estradiol is a more effective bone-sparing and anabolic agent than 5alpha-dihydrotestosterone. J. Bone Miner. Res. 2002, 17, 2080-2086. [CrossRef] [PubMed]

164. Kousteni, S.; Chen, J.R.; Bellido, T.; Han, L.; Ali, A.A.; O’Brien, C.A.; Plotkin, L.; Fu, Q.; Mancino, A.T.; Wen, Y.; et al. Reversal of bone loss in mice by nongenotropic signaling of sex steroids. Science 2002, 298, 843-846. [PubMed]

165. Ishimi, Y.; Miyaura, C.; Ohmura, M.; Onoe, Y.; Sato, T.; Uchiyama, Y.; Ito, M.; Wang, X.; Suda, T.; Ikegami, S. Selective effects of genistein, a soybean isoflavone, on b-lymphopoiesis and bone loss caused by estrogen deficiency. Endocrinology 1999, 140, 1893-1900. [CrossRef]

166. Ishimi, Y.; Yoshida, M.; Wakimoto, S.; Wu, J.; Chiba, H.; Wang, X.; Takeda, K.; Miyaura, C. Genistein, a soybean isoflavone, affects bone marrow lymphopoiesis and prevents bone loss in castrated male mice. Bone 2002, 31, 180-185. [CrossRef]

167. Vandenput, L. The Role of Aromatization of Androgens in Oestrogens and of the Oestrogen Receptors in the Development and Maintance of the Male Skeleton; Leuven University Press: Leuven, Belgium, 2002.

168. Cheng, B.H.; Chu, T.M.; Chang, C.; Kang, H.Y.; Huang, K.E. Testosterone delivered with a scaffold is as effective as bone morphologic protein-2 in promoting the repair of critical-size segmental defect of femoral bone in mice. PLoS ONE 2013, 8, e70234. [CrossRef]

169. Vidal, O.; Lindberg, M.K.; Hollberg, K.; Baylink, D.J.; Andersson, G.; Lubahn, D.B.; Mohan, S.; Gustafsson, J.A.; Ohlsson, C. Estrogen receptor specificity in the regulation of skeletal growth and maturation in male mice. Proc. Natl. Acad. Sci. USA 2000, 97, 5474-5479. [CrossRef]

170. Ke, H.Z.; Brown, T.A.; Qi, H.; Crawford, D.T.; Simmons, H.A.; Petersen, D.N.; Allen, M.R.; McNeish, J.D.; Thompson, D.D. The role of estrogen receptor-beta, in the early age-related bone gain and later age-related bone loss in female mice. J. Musculoskelet. Neuronal Interact. 2002, 2, 479-488.

171. Mohamad, N.V.; Soelaiman, I.N.; Chin, K.Y. A concise review of testosterone and bone health. Clin. Interv. Aging 2016, 11, 1317-1324. [CrossRef] 
172. Wiren, K.M.; Semirale, A.A.; Hashimoto, J.G.; Zhang, X.W. Signaling pathways implicated in androgen regulation of endocortical bone. Bone 2010, 46, 710-723. [CrossRef]

173. Wiren, K.M.; Hashimoto, J.G.; Semirale, A.A.; Zhang, X.W. Bone vs. Fat: Embryonic origin of progenitors determines response to androgen in adipocytes and osteoblasts. Bone 2011, 49, 662-672. [CrossRef] [PubMed]

174. Semirale, A.A.; Zhang, X.W.; Wiren, K.M. Body composition changes and inhibition of fat development in vivo implicates androgen in regulation of stem cell lineage allocation. J. Cell. Biochem. 2011, 112, 1773-1786. [CrossRef] [PubMed]

175. Wiren, K.M.; Zhang, X.W.; Toombs, A.R.; Kasparcova, V.; Gentile, M.A.; Harada, S.; Jepsen, K.J. Targeted overexpression of androgen receptor in osteoblasts: Unexpected complex bone phenotype in growing animals. Endocrinology 2004, 145, 3507-3522. [CrossRef] [PubMed]

176. Wiren, K.M.; Zhang, X.W.; Olson, D.A.; Turner, R.T.; Iwaniec, U.T. Androgen prevents hypogonadal bone loss via inhibition of resorption mediated by mature osteoblasts/osteocytes. Bone 2012, 51, 835-846. [CrossRef] [PubMed]

177. Notini, A.J.; McManus, J.F.; Moore, A.; Bouxsein, M.; Jimenez, M.; Chiu, W.S.; Glatt, V.; Kream, B.E.; Handelsman, D.J.; Morris, H.A.; et al. Osteoblast deletion of exon 3 of the androgen receptor gene results in trabecular bone loss in adult male mice. J. Bone Miner. Res. 2007, 22, 347-356. [CrossRef]

178. Kawano, H.; Sato, T.; Yamada, T.; Matsumoto, T.; Sekine, K.; Watanabe, T.; Nakamura, T.; Fukuda, T.; Yoshimura, K.; Yoshizawa, T.; et al. Suppressive function of androgen receptor in bone resorption. Proc. Natl. Acad. Sci. USA 2003, 100, 9416-9421. [CrossRef]

179. Khosla, S.; Monroe, D.G. Regulation of bone metabolism by sex steroids. Cold Spring Harb. Perspect. Med. 2018, 8, a031211. [CrossRef]

180. Chiang, C.; Chiu, M.; Moore, A.J.; Anderson, P.H.; Ghasem-Zadeh, A.; McManus, J.F.; Ma, C.; Seeman, E.; Clemens, T.L.; Morris, H.A.; et al. Mineralization and bone resorption are regulated by the androgen receptor in male mice. J. Bone Miner. Res. 2009, 24, 621-631. [CrossRef]

181. Wang, X.; Li, F.; Niyibizi, C. Progenitors systemically transplanted into neonatal mice localize to areas of active bone formation in vivo: Implications of cell therapy for skeletal diseases. Stem Cells 2006, 24, 1869-1878. [CrossRef]

182. Mohamed-Ahmed, S.; Fristad, I.; Lie, S.A.; Suliman, S.; Mustafa, K.; Vindenes, H.; Idris, S.B. Adipose-derived and bone marrow mesenchymal stem cells: A donor-matched comparison. Stem Cell Res. Ther. 2018, 9, 168. [CrossRef]

183. Horwitz, E.M.; Prockop, D.J.; Fitzpatrick, L.A.; Koo, W.W.; Gordon, P.L.; Neel, M.; Sussman, M.; Orchard, P.; Marx, J.C.; Pyeritz, R.E.; et al. Transplantability and therapeutic effects of bone marrow-derived mesenchymal cells in children with osteogenesis imperfecta. Nat. Med. 1999, 5, 309-313. [CrossRef] [PubMed]

184. Colvard, D.S.; Eriksen, E.F.; Keeting, P.E.; Wilson, E.M.; Lubahn, D.B.; French, F.S.; Riggs, B.L.; Spelsberg, T.C. Identification of androgen receptors in normal human osteoblast-like cells. Proc. Natl. Acad. Sci. USA 1989, 86, 854-857. [CrossRef] [PubMed]

185. Nordstrand, A.; Bovinder Ylitalo, E.; Thysell, E.; Jernberg, E.; Crnalic, S.; Widmark, A.; Bergh, A.; Lerner, U.H.; Wikstrom, P. Bone cell activity in clinical prostate cancer bone metastasis and its inverse relation to tumor cell androgen receptor activity. Int. J. Mol. Sci. 2018, 19, E1223. [CrossRef] [PubMed]

186. Orwoll, E.S.; Stribrska, L.; Ramsey, E.E.; Keenan, E.J. Androgen receptors in osteoblast-like cell lines. Calcif. Tissue Int. 1991, 49, 183-187. [CrossRef]

187. Wiren, K.; Keenan, E.; Zhang, X.; Ramsey, B.; Orwoll, E. Homologous androgen receptor up-regulation in osteoblastic cells may be associated with enhanced functional androgen responsiveness. Endocrinology 1999, 140, 3114-3124. [CrossRef]

188. Czerwiec, F.S.; Liaw, J.J.; Liu, S.B.; Perez-Stable, C.; Grumbles, R.; Howard, G.A.; Roos, B.A.; Burnstein, K.L. Absence of androgen-mediated transcriptional effects in osteoblastic cells despite presence of androgen receptors. Bone 1997, 21, 49-56. [CrossRef]

189. Takeuchi, M.; Kakushi, H.; Tohkin, M. Androgens directly stimulate mineralization and increase androgen receptors in human osteoblast-like osteosarcoma cells. Biochem. Biophys. Res. Commun. 1994, 204, 905-911. [CrossRef]

190. Nakano, Y.; Morimoto, I.; Ishida, O.; Fujihira, T.; Mizokami, A.; Tanimoto, A.; Yanagihara, N.; Izumi, F.; Eto, S. The receptor, metabolism and effects of androgen in osteoblastic mc3t3-e1 cells. Bone Miner. 1994, 26, 245-259. [CrossRef] 
191. Liesegang, P.; Romalo, G.; Sudmann, M.; Wolf, L.; Schweikert, H.U. Human osteoblast-like cells contain specific, saturable, high-affinity glucocorticoid, androgen, estrogen, and 1 alpha,25-dihydroxycholecalciferol receptors. J. Androl. 1994, 15, 194-199.

192. Masuyama, A.; Ouchi, Y.; Sato, F.; Hosoi, T.; Nakamura, T.; Orimo, H. Characteristics of steroid hormone receptors in cultured mc3t3-e1 osteoblastic cells and effect of steroid hormones on cell proliferation. Calcif. Tissue Int. 1992, 51, 376-381. [CrossRef]

193. Benz, D.J.; Haussler, M.R.; Thomas, M.A.; Speelman, B.; Komm, B.S. High-affinity androgen binding and androgenic regulation of alpha 1(i)-procollagen and transforming growth factor-beta steady state messenger ribonucleic acid levels in human osteoblast-like osteosarcoma cells. Endocrinology 1991, 128, 2723-2730. [CrossRef] [PubMed]

194. Bland, R. Steroid hormone receptor expression and action in bone. Clin. Sci. 2000, 98, 217-240. [CrossRef] [PubMed]

195. Chiang, C.Y. The Role of Androgens Acting via the Androgen Receptor in Osteoblasts to Regulate Bone Cell Metabolism. Ph.D. Thesis, The University of Melbourne, Melbourne, Australia, December 2017.

196. Zhuang, Y.H.; Blauer, M.; Pekki, A.; Tuohimaa, P. Subcellular location of androgen receptor in rat prostate, seminal vesicle and human osteosarcoma mg-63 cells. J. Steroid Biochem. Mol. Biol. 1992, 41, 693-696. [CrossRef]

197. Wiren, K.M.; Zhang, X.; Chang, C.; Keenan, E.; Orwoll, E.S. Transcriptional up-regulation of the human androgen receptor by androgen in bone cells. Endocrinology 1997, 138, 2291-2300. [CrossRef] [PubMed]

198. Hofbauer, L.C.; Hicok, K.C.; Schroeder, M.J.; Harris, S.A.; Robinson, J.A.; Khosla, S. Development and characterization of a conditionally immortalized human osteoblastic cell line stably transfected with the human androgen receptor gene. J. Cell. Biochem. 1997, 66, 542-551. [CrossRef]

199. Wiren, K.M.; Chapman Evans, A.; Zhang, X.W. Osteoblast differentiation influences androgen and estrogen receptor-alpha and -beta expression. J. Endocrinol. 2002, 175, 683-694. [CrossRef]

200. Gruber, R.; Czerwenka, K.; Wolf, F.; Ho, G.M.; Willheim, M.; Peterlik, M. Expression of the vitamin d receptor, of estrogen and thyroid hormone receptor alpha- and beta-isoforms, and of the androgen receptor in cultures of native mouse bone marrow and of stromal/osteoblastic cells. Bone 1999, 24, 465-473. [CrossRef]

201. Mantalaris, A.; Panoskaltsis, N.; Sakai, Y.; Bourne, P.; Chang, C.; Messing, E.M.; Wu, J.H. Localization of androgen receptor expression in human bone marrow. J. Pathol. 2001, 193, 361-366. [CrossRef]

202. Huang, C.K.; Luo, J.; Lee, S.O.; Chang, C. Concise review: Androgen receptor differential roles in stem/progenitor cells including prostate, embryonic, stromal, and hematopoietic lineages. Stem Cells 2014, 32, 2299-2308. [CrossRef]

203. Braidman, I.P.; Hainey, L.; Batra, G.; Selby, P.L.; Saunders, P.T.; Hoyland, J.A. Localization of estrogen receptor beta protein expression in adult human bone. J. Bone Miner. Res. 2001, 16, 214-220. [CrossRef]

204. Abu, E.O.; Horner, A.; Kusec, V.; Triffitt, J.T.; Compston, J.E. The localization of androgen receptors in human bone. J. Clin. Endocrinol. Metab. 1997, 82, 3493-3497. [CrossRef] [PubMed]

205. Tsai, M.Y.; Shyr, C.R.; Kang, H.Y.; Chang, Y.C.; Weng, P.L.; Wang, S.Y.; Huang, K.E.; Chang, C. The reduced trabecular bone mass of adult arko male mice results from the decreased osteogenic differentiation of bone marrow stroma cells. Biochem. Biophys. Res. Commun. 2011, 411, 477-482. [CrossRef] [PubMed]

206. Huang, C.K.; Lai, K.P.; Luo, J.; Tsai, M.Y.; Kang, H.Y.; Chen, Y.; Lee, S.O.; Chang, C. Loss of androgen receptor promotes adipogenesis but suppresses osteogenesis in bone marrow stromal cells. Stem Cell Res. 2013, 11, 938-950. [CrossRef] [PubMed]

207. Kang, H.Y.; Shyr, C.R.; Huang, C.K.; Tsai, M.Y.; Orimo, H.; Lin, P.C.; Chang, C.; Huang, K.E. Altered tnsalp expression and phosphate regulation contribute to reduced mineralization in mice lacking androgen receptor. Mol. Cell. Biol. 2008, 28, 7354-7367. [CrossRef]

208. Yatsu, T.; Kusakabe, T.; Kato, K.; Inouye, Y.; Nemoto, K.; Kanno, Y. Selective androgen receptor modulator, yk11, up-regulates osteoblastic proliferation and differentiation in mc3t3-e1 cells. Biol. Pharm. Bull. 2018, 41, 394-398. [CrossRef]

209. Chang, C.; Yeh, S.; Lee, S.O.; Chang, T.M. Androgen receptor (ar) pathophysiological roles in androgen-related diseases in skin, bone/muscle, metabolic syndrome and neuron/immune systems: Lessons learned from mice lacking ar in specific cells. Nucl. Recept. Signal. 2013, 11, e001. [CrossRef] 
210. Chang, C.Y.; Hsuuw, Y.D.; Huang, F.J.; Shyr, C.R.; Chang, S.Y.; Huang, C.K.; Kang, H.Y.; Huang, K.E. Androgenic and antiandrogenic effects and expression of androgen receptor in mouse embryonic stem cells. Fertil. Steril. 2006, 85, 1195-1203. [CrossRef]

211. Davies, A.H.; Zoubeidi, A. The androgen receptor bridges stem cell-associated signaling nodes in prostate stem cells. Stem Cells Int. 2016, 2016, 4829602. [CrossRef]

212. Huang, C.K.; Lee, S.O.; Lai, K.P.; Ma, W.L.; Lin, T.H.; Tsai, M.Y.; Luo, J.; Chang, C. Targeting androgen receptor in bone marrow mesenchymal stem cells leads to better transplantation therapy efficacy in liver cirrhosis. Hepatology 2013, 57, 1550-1563. [CrossRef]

213. Huang, C.K.; Tsai, M.Y.; Luo, J.; Kang, H.Y.; Lee, S.O.; Chang, C. Suppression of androgen receptor enhances the self-renewal of mesenchymal stem cells through elevated expression of egfr. Biochim. Biophys. Acta 2013, 1833, 1222-1234. [CrossRef]

214. Elraiyah, T.; Sonbol, M.B.; Wang, Z.; Khairalseed, T.; Asi, N.; Undavalli, C.; Nabhan, M.; Firwana, B.; Altayar, O.; Prokop, L.; et al. Clinical review: The benefits and harms of systemic testosterone therapy in postmenopausal women with normal adrenal function: A systematic review and meta-analysis. J. Clin. Endocrinol. Metab. 2014, 99, 3543-3550. [CrossRef]

215. Dexheimer, V.; Mueller, S.; Braatz, F.; Richter, W. Reduced reactivation from dormancy but maintained lineage choice of human mesenchymal stem cells with donor age. PLoS ONE 2011, 6, e22980. [CrossRef] [PubMed]

216. Fossett, E.; Khan, W.S. Optimising human mesenchymal stem cell numbers for clinical application: A literature review. Stem Cells Int. 2012, 2012, 465259. [CrossRef] [PubMed]

217. Fuente-Martin, E.; Argente-Arizon, P.; Ros, P.; Argente, J.; Chowen, J.A. Sex differences in adipose tissue: It is not only a question of quantity and distribution. Adipocyte 2013, 2, 128-134. [CrossRef] [PubMed]

218. Fitzgerald, S.J.; Janorkar, A.V.; Barnes, A.; Maranon, R.O. A new approach to study the sex differences in adipose tissue. J. Biomed. Sci. 2018, 25, 89. [CrossRef] [PubMed]

219. Simpson, A.; Petnga, W.; Macaulay, V.M.; Weyer-Czernilofsky, U.; Bogenrieder, T. Insulin-like growth factor (igf) pathway targeting in cancer: Role of the igf axis and opportunities for future combination studies. Target. Oncol. 2017, 12, 571-597. [CrossRef]

220. Park, H.J.; Choi, J.M. Sex-specific regulation of immune responses by ppars. Exp. Mol. Med. 2017, 49 , e364. [CrossRef]

221. Davis, S.R.; McCloud, P.; Strauss, B.J.; Burger, H. Testosterone enhances estradiol's effects on postmenopausal bone density and sexuality. Maturitas 2008, 61, 17-26. [CrossRef]

222. Savvas, M.; Studd, J.W.; Fogelman, I.; Dooley, M.; Montgomery, J.; Murby, B. Skeletal effects of oral oestrogen compared with subcutaneous oestrogen and testosterone in postmenopausal women. BMJ 1988, 297, 331-333. [CrossRef]

223. Raisz, L.G.; Wiita, B.; Artis, A.; Bowen, A.; Schwartz, S.; Trahiotis, M.; Shoukri, K.; Smith, J. Comparison of the effects of estrogen alone and estrogen plus androgen on biochemical markers of bone formation and resorption in postmenopausal women. J. Clin. Endocrinol. Metab. 1996, 81, 37-43.

224. Watts, N.B.; Notelovitz, M.; Timmons, M.C.; Addison, W.A.; Wiita, B.; Downey, L.J. Comparison of oral estrogens and estrogens plus androgen on bone mineral density, menopausal symptoms, and lipid-lipoprotein profiles in surgical menopause. Obstet. Gynecol. 1995, 85, 529-537. [CrossRef]

225. Savvas, M.; Studd, J.W.; Norman, S.; Leather, A.T.; Garnett, T.J.; Fogelman, I. Increase in bone mass after one year of percutaneous oestradiol and testosterone implants in post-menopausal women who have previously received long-term oral oestrogens. Br. J. Obstet. Gynaecol. 1992, 99, 757-760. [CrossRef] [PubMed]

226. Tracz, M.J.; Sideras, K.; Bolona, E.R.; Haddad, R.M.; Kennedy, C.C.; Uraga, M.V.; Caples, S.M.; Erwin, P.J.; Montori, V.M. Testosterone use in men and its effects on bone health. A systematic review and meta-analysis of randomized placebo-controlled trials. J. Clin. Endocrinol. Metab. 2006, 91, 2011-2016. [CrossRef] [PubMed]

227. Permpongkosol, S.; Khupulsup, K.; Leelaphiwat, S.; Pavavattananusorn, S.; Thongpradit, S.; Petchthong, T. Effects of 8-year treatment of long-acting testosterone undecanoate on metabolic parameters, urinary symptoms, bone mineral density, and sexual function in men with late-onset hypogonadism. J. Sex. Med. 2016, 13, 1199-1211. [CrossRef] [PubMed]

228. Falahati-Nini, A.; Riggs, B.L.; Atkinson, E.J.; O’Fallon, W.M.; Eastell, R.; Khosla, S. Relative contributions of testosterone and estrogen in regulating bone resorption and formation in normal elderly men. J. Clin. Investig. 2000, 106, 1553-1560. [CrossRef] 
229. Narayanan, R.; Coss, C.C.; Dalton, J.T. Development of selective androgen receptor modulators (sarms). Mol. Cell. Endocrinol. 2018, 465, 134-142. [CrossRef]

230. Hanada, K.; Furuya, K.; Yamamoto, N.; Nejishima, H.; Ichikawa, K.; Nakamura, T.; Miyakawa, M.; Amano, S.; Sumita, Y.; Oguro, N. Bone anabolic effects of s-40503, a novel nonsteroidal selective androgen receptor modulator (sarm), in rat models of osteoporosis. Biol. Pharm. Bull. 2003, 26, 1563-1569. [CrossRef]

231. Kearbey, J.D.; Gao, W.; Narayanan, R.; Fisher, S.J.; Wu, D.; Miller, D.D.; Dalton, J.T. Selective androgen receptor modulator (sarm) treatment prevents bone loss and reduces body fat in ovariectomized rats. Pharm. Res. 2007, 24, 328-335. [CrossRef]

232. Dobs, A.S.; Boccia, R.V.; Croot, C.C.; Gabrail, N.Y.; Dalton, J.T.; Hancock, M.L.; Johnston, M.A.; Steiner, M.S. Effects of enobosarm on muscle wasting and physical function in patients with cancer: A double-blind, randomised controlled phase 2 trial. Lancet Oncol. 2013, 14, 335-345. [CrossRef]

233. Crawford, J.; Prado, C.M.; Johnston, M.A.; Gralla, R.J.; Taylor, R.P.; Hancock, M.L.; Dalton, J.T. Study design and rationale for the phase 3 clinical development program of enobosarm, a selective androgen receptor modulator, for the prevention and treatment of muscle wasting in cancer patients (power trials). Curr. Oncol. Rep. 2016, 18, 37. [CrossRef]

(C) 2019 by the authors. Licensee MDPI, Basel, Switzerland. This article is an open access article distributed under the terms and conditions of the Creative Commons Attribution (CC BY) license (http://creativecommons.org/licenses/by/4.0/). 